\title{
Gene expression in the developing nemertean brain indicates convergent evolution of complex brains in Spiralia
}

Ludwik Gąsiorowski ${ }^{1}$, Aina Børve ${ }^{1}$, Irina A. Cherneva ${ }^{2}$, Andrea Orús-Alcalde ${ }^{1}$, Andreas Hejnol ${ }^{*}$

\author{
${ }^{1}$ Department of Biological Sciences, University of Bergen, Bergen, Norway \\ ${ }^{2}$ Biological Faculty, M.V. Lomonosov Moscow State University, Moscow, Russia \\ *correspondence: andreas.hejnol@uib.no
}

ORCID: Ludwik Gąsiorowski: 0000-0003-2238-7587, Aina Børve: 0000-0003-0311-5156,

Andrea Orús-Alcalde: 0000-0003-2381-2530, Andreas Hejnol: 0000-0003-2196-8507

\begin{abstract}
Background: Nemertea is a clade of worm-like animals, which belongs to a larger animal group called Spiralia (together with e.g. annelids, flatworms and mollusks). Many of the nemertean species possess a complex central nervous system (CNS) with a prominent brain, and elaborated chemosensory and neuroglandular cerebral organs, which have been suggested as homologues to the annelid mushroom bodies. In order to understand the developmental and evolutionary origins of complex nemertean brain, we investigated details of neuroanatomy and gene expression in the brain and cerebral organs of the juveniles of nemertean Lineus ruber.
\end{abstract}

Results: In the hatched juveniles the CNS is already composed of all major elements present in the adults, including the brain (with dorsal and ventral lobes), paired longitudinal lateral 
nerve cords and an unpaired dorsal nerve cord. The TEM investigation of the juvenile cerebral organ revealed that the structure is already composed of several distinct cell types present also in the adults. We further investigated the expression of twelve transcription factors commonly used as brain and cell type markers in bilaterian brains, including genes specific for annelid mushroom bodies. The expression of the investigated genes in the brain is regionspecific and divides the entire organ into several molecularly distinct areas, partially overlapping with the morphological compartments. Additionally, we detected expression of mushroom body specific genes in the developing cerebral organs.

Conclusions: At the moment of hatching, the juveniles of $L$. ruber already have a similar neuroarchitecture as adult worms, which suggests that further neural development is mostly related with increase in the size but not in complexity. Comparison in the gene expression between L. ruber and the annelid Platynereis dumerilii and other spiralians, indicates that the complex brains present in those two species evolved convergently by independent expansion of non-homologues regions of the simpler brain present in their common ancestor. The similarities in gene expression in mushroom bodies and cerebral organs might be a result of the convergent recruitment of the same genes into patterning of non-homologues organs or the results of more complicated evolutionary processes, in which conserved and novel cell types contribute to the non-homologues structures.

\section{Key words:}

CNS, brain patterning, neuroanatomy 


\section{Background}

Nemertea is a clade of ca. 1300 described species of unsegmented worms, which predominantly occur in marine environments [1-3]. Phylogenetically, they belong to the large animal group called Spiralia (together with e.g. annelids, mollusks and flatforms) [4-12], however, despite recent progress in molecular phylogenetics, their exact position on the spiralian tree of life remains controversial $[6-8,10,13]$.

Most nemerteans are active predators, which hunt for their invertebrate prey using a specialized eversible proboscis, a morphological apomorphy of the clade $[1,14-18]$. This active lifestyle is accompanied by a relatively complex nervous system, composed of a large, multilobed brain (with two ventral and two dorsal lobes), a pair of lateral medullary nerve cords, extensive peripheral network and multiple specialized sensory organs [17-29]. Among the latter, the most conspicuous are the so-called cerebral (or cephalic) organs - paired structures of neurosecretory and either chemo- or mechanosensory function, located on the lateral sides of the head [17-23, 28, 30-33]. The exact arrangement of the cerebral organs varies between nemertean clades from relatively simple ciliated pits present in some Tubulaniformes, to the complex neuroglandular structures connected both directly to the brain and, through the convoluted ciliated canal, to the external environment in lineid heteronemerteans $[17-23,27,28,32,33]$. The phylogenetic analysis of morphological traits in nemerteans indicated that cerebral organs were already present in the last common nemertean ancestor [20]. However, it remains unclear, whether the cerebral organs represent an autapomorphy of nemerteans or homologs to some organs present in other spiralians such as ciliated pits of flatworms $[30,34]$ or mushroom bodies of annelids $[19,35$, 36]. 
In the present study, we describe the detailed morphology of the nervous system and gene expression in the brain and cerebral organs of the juveniles of Lineus ruber (Müller, 1774), a directly developing lineid heteronemertean. L. ruber has been studied in past for both adult morphology [20, 22-26, 29-31] and some aspects of its development [29, 37, 38], including the molecular patterning of anterior-posterior axis, germ layers and lateral nerve cords [39, 40]. Comparison of our data with the existing morphological descriptions of the adult nervous system in L. ruber [20, 22-26, 29-31] and other closely related species, allows a better understanding of the ontogeny of the complex nemertean nervous system. Additionally, juxtaposition of gene expression profiles in the developing brain of $L$. ruber with that of other Spiralia $[39,41-48]$ can pinpoint similarities and differences in the molecular patterning of the spiralian brains in general, which in turn can inform evolution of the complex nemertean brain. Moreover, by comparing gene expression in cerebral organs of $L$. ruber and mushroom bodies of a comprehensively studied annelid P. dumerilii [49], we can provide new data to test the homology hypothesis of the cerebral organs of nemerteans and mushroom bodies of annelids.

\section{Results}

Morphology of the nervous system in the juvenile L. ruber

The investigated juveniles of $L$. ruber were freshly hatched from the egg mass, 42 days after oviposition [40]. We visualized the nervous system of the juveniles by applying antibody staining against tyrosinated tubulin, FMRF-amide and serotonin (5-HT), as well as Sytox green nuclear staining and fluorescent in situ mRNA hybridization of the choline acetyltransferase (ChAT), a genetic marker of the cholinergic neurons [50]. 


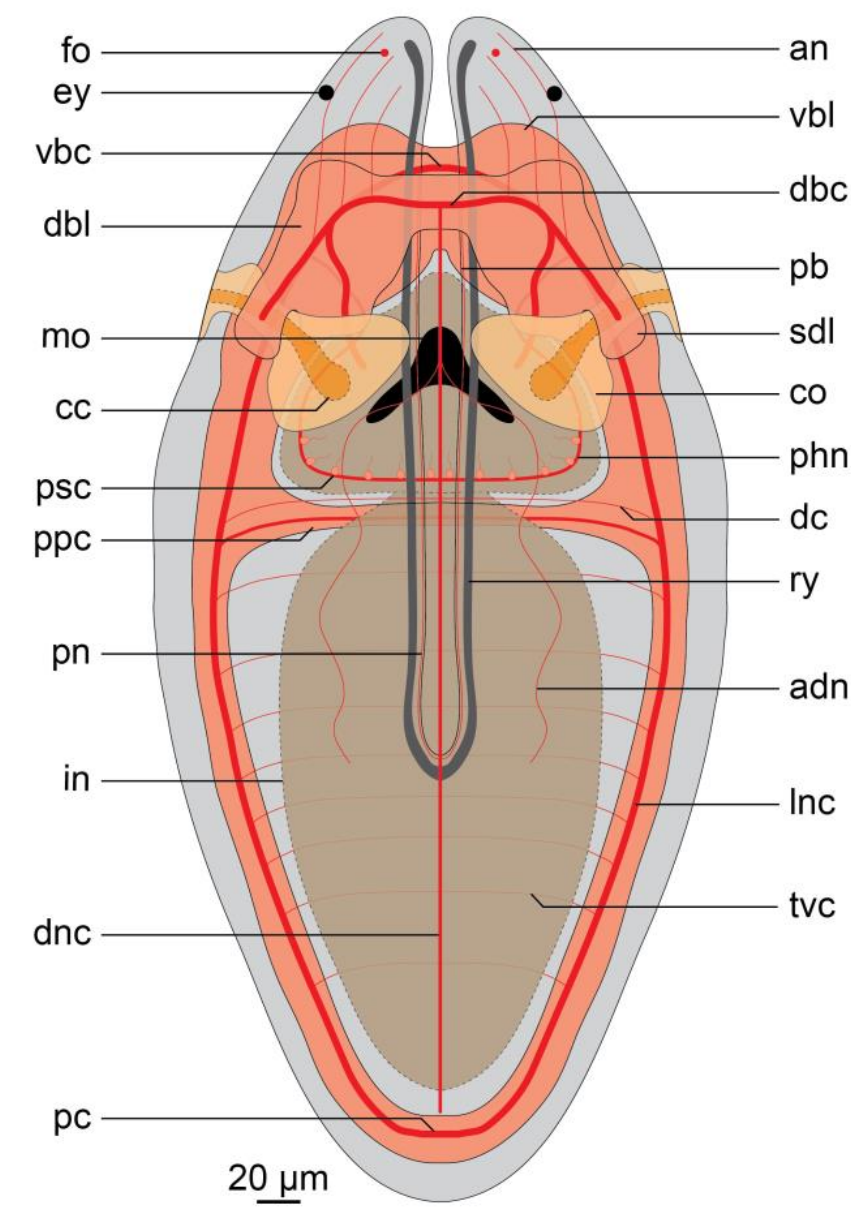

Fig. 1. Schematic drawing of the nervous system in 42 days old juveniles of Lineus ruber. Anterior is to the top. Abbreviations: adn accessory dorsal nerve, an anterior nerve, cc ciliated canal, co cerebral organ, $d b c$ dorsal brain commissure, $d b /$ dorsal brain lobe, $d c$ dorsal commissure, dnc dorsal nerve cord, ey eye, fo frontal organ, in intestine, Inc lateral nerve cord, mo mouth opening, $p b$ proboscis, $p c$ posterior commissure, phn pharyngeal nerve, $p n$ proboscis nerve, $p p c$ postpharyngeal commissure, psc pharyngeal sensory cell, ry rhynchocoel, sdl superior branch of the dorsal lobe, tvc transverse ventral commissure, $v b c$ ventral brain commissure, vb/ ventral brain lobe.

42 days old juveniles have already all major components of the nervous system (Figs. 1 and 2), which is composed of: 1) central nervous system (CNS) with brain, two lateral nerve cords (LNCs) connected by a postpharyngeal and posterior commissures and a single dorsal nerve cord (DNC); 2) stomatogastric nervous system (SNS), especially well developed in the pharyngeal region; 3 ) innervation of the proboscis; 4) network of fine peripheral nerves; 5) a pair of large cerebral organs; and 6) other sensory structures such as frontal organs and frontal sensory nerves.

The brain is located anteriorly and is divided into four lobes: two ventral ( $v b l$, Figs. 1 and 2B, $\mathrm{F}, \mathrm{H}, \mathrm{I})$ and two dorsal ones ( $d b$, Figs. 1 and $2 \mathrm{~A}, \mathrm{E})$. Each lobe is composed of the internal neuropile and the external layer of perikarya (Fig. $2 \mathrm{C}-\mathrm{F}, \mathrm{J}$ ). Anteriorly both dorsal and ventral 
lobes are connected by dorsal ( $d b c$ Figs. 1 and $2 A, C, E, G, I)$ and ventral ( $v b c$ Figs. 1 and 2B, D, $\mathrm{F}, \mathrm{H}-\mathrm{J}$ ) brain commissures, respectively. Thus, the brain neuropile forms a ring around rhynchocoel and proboscis (Fig. 1). Posteriorly, each dorsal brain lobe is further divided into an inferior and a superior branch. The former connects directly to the cerebral organ (see below), while the latter ends blindly on the dorsal side of the animal (Figs. 1 and 2E). The neuropiles of the ventral lobes posteriorly give rise to the LNCs (Fig. 2D, H, J). FMRF-amidelike immunoreactive (FLIR) perikarya and $\mathrm{ChAT}^{+}$cells have been observed in both dorsal and ventral brain lobes (Fig. $2 A-F$ ), while serotonin-like immunoreactive (SLIR) perikarya are present only in the ventral lobes (Fig. $2 \mathrm{H}-\mathrm{J}$ ). Both dorsal and ventral commissures and neuropiles of all brain lobes are composed of FLIR, SLIR and tyrosinated tubulin-like immunoreactive (TLIR) neurites (Fig. 2 A-D, G-J).

Three longitudinal nerve cords originate from the brain: a pair of thick LNCs (Inc, Figs. 1 and 2A, B, D, F, H-J) and a finer, unpaired DNC (dnc, Figs. 1, 2A, G, I). The LNCs are composed of an external layer of perikarya and an internal neuropile (and hence represent medullary nerve cords [51]). The neuropiles are densely packed with TLIR, SLIR and FLIR neurites (Inc, Fig. 2 A, B, D, H-J), while numerous $C h A T^{+}$neuronal cell bodies as well as more sparsely distributed FLIR and SLIR perikarya are mostly present in the anterior section of each LNC (Fig. 2B, D, F, I, J). The LNCs are connected behind the pharynx by a medullary postpharyngeal commissure (ppc, Figs. 2B, $\mathrm{F}, \mathrm{H}, \mathrm{J}$ ), which is composed of TLIR and SLIR neurites as well as few SLIR and numerous ChAT $T^{+}$perikarya (Fig. $2 \mathrm{~F}$ and J). At the end of the animal body, both LNCs converge in a posterior commissure ( $p c$, Figs. $1,2 \mathrm{~B}, \mathrm{H}$ ), which shows the same immunoreactivity patterns as neuropiles of LNCs. The DNC originates from the dorsal brain commissure. Compared to the LNCs, it is much finer and does not seem to be associated with any perikarya (Figs. 2A, G, I). It is composed of only a few TLIR and SLIR neurites, while anteriorly, a pair of 
fine FLIR dorsal accessory nerves branch out from it (adn, Figs. 1 and 2A). At the level of the pharynx, a fine, SLIR and TLIR dorsal commissure connects dorsal and lateral nerve cords ( $d c$, Figs. 1 and 2I).

The SNS is composed of thick TLIR, FLIR and SLIR pharyngeal nerves, which originate from the ventral brain lobes and meander around the pharynx (phn, Figs. 1, 2C, D, J). Numerous sensory FLIR and SLIR cells are located along the pharyngeal nerves (psc, Fig. 1; double arrowheads Fig. 2D, J). Each of those cells has a basal connection to the pharyngeal nerve and an apical process pointing towards the pharyngeal lumen.

Some neural structures are also associated with the proboscis. Two longitudinal TLIR and FLIR nerves extend along the proboscis ( $p n$, Figs. 1 and $2 \mathrm{C}$ ), however their exact origin in the brain remains unclear. Scattered $\mathrm{ChAT}^{+}$cells, of probably sensory function, are present in the epidermis of the proboscis (yellow arrowheads, inset in Fig. 2E).

The extensive network of peripheral nerves was detected, especially evident on the ventral side of the animal. It is composed of regular transverse ventral TLIR commissures (tvc, Fig. 1; arrowheads, Fig. 2B), some of which are additionally SLIR (arrowheads, Fig. $2 \mathrm{H}-\mathrm{J}$ ). A less regular network of SLIR intraepidermal neurites is present on both dorsal and ventral sides of the juvenile (Fig. 2 G-J).

A pair of conspicuous cerebral organs is located on the lateral sides of the head, just behind the brain (co, Figs. 1, 2C and E). More details of their morphology can be found in the following section. Other sensory structures, detected in addition to the cerebral organs, includes FLIR and $\mathrm{ChAT}^{+}$anterior sensory cells (asc, Figs. 1 and $2 \mathrm{C}, \mathrm{E}$ ), which likely contribute to the socalled frontal organs $[19,22,23,25]$, and numerous SLIR cephalic nerves extending anteriorly from the brain (an, Figs. 1 and 2H). Although 42 days old juveniles already possess rudiments of eyespots [40], we were not able to conclusively detect them in our investigation. 

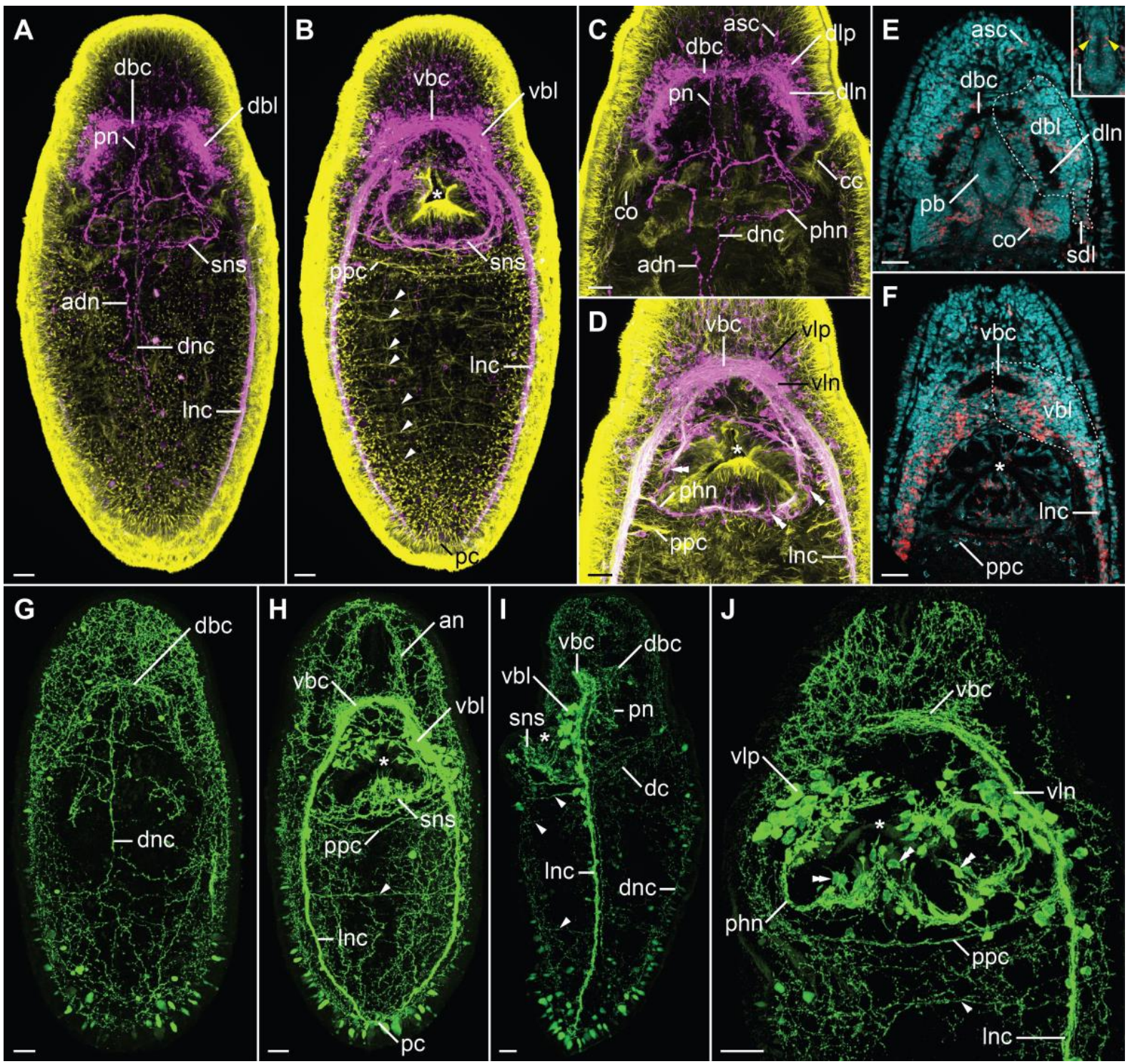

Fig. 2. Morphology of the nervous system in 42 days old juveniles of $L$. ruber visualized with CLSM and antibody staining against tyrosinated tubulin (yellow, panels A-D), FMRF-amide (magenta, panels AD) and serotonin (green, panels $\mathbf{G}-\mathbf{J}$ ) as well as Sytox green nuclear staining (cyan, panels $\mathbf{E}, \mathbf{F}$ ) and in situ hybridization with probe against choline acetyltransferase (red, panels $\mathbf{E}$, F). Entire animal in dorso-ventral projection with a focus on dorsal $(\mathbf{A}, \mathbf{G})$ and ventral $(\mathbf{B}, \mathbf{H})$ structures; anterior part of the animal in dorso-ventral projection with a focus on dorsal (C, E) and ventral (D, F, J) structures, inset in panel $\mathbf{E}$ shows ChAT expression in the proboscis (yellow arrowheads); I lateral projection of the entire animal. Anterior is to the top on all panels. Scale bars $20 \mu \mathrm{m}$. Abbreviations: adn accessory dorsal nerve, an anterior nerve, asc anterior sensory cell, $c c$ ciliated canal, co cerebral organ, $d b c$ dorsal brain commissure, $d b /$ dorsal brain lobe, $d c$ dorsal commissure, $d l n$ dorsal lobe neuropile, $d l p$ dorsal lobe perikaryon, $d n c$ dorsal nerve cord, Inc lateral nerve cord, $p b$ proboscis, $p c$ posterior commissure, phn pharyngeal nerve, pn proboscis nerve, ppc postpharyngeal commissure, sdl superior branch of the dorsal lobe, sns stomatogastric nervous system, $v b c$ ventral brain commissure, vb/ ventral brain lobe, $v / n$ ventral lobe neuropile, v/p vetral lobe perikaryon. White arrowheads indicate transverse ventral commissures, double white arrowheads pharyngeal sensory cells and asterisks the mouth opening. 
EdU staining in 60 days old juveniles showed that most of the brain cells at this later developmental stage are not mitotically active in contrast to the cells in other organs, such as proboscis, rhynchocoel or cerebral organs (Fig. 3A and B).

\section{Detailed morphology of the cerebral organs}

Each cerebral organ is composed of two parts: a distal ciliated canal (cc, Figs. 1, 2C, 4B, C), which opens to the exterior on the side of the head (in the posterior part of the so called lateral cephalic slit), and a proximal neuroglandular portion (co, Figs. 1, 2C). The lumen of the ciliated canal is slightly curved in $\mathbf{4 2}$ days old juveniles, but the characteristic triple right-angle bends, present in the adult lineids [30-32] are not yet evident (cc, Fig. $2 \mathrm{C}$ ). The ciliated canal connects the external environment with the neuroglandular part, which itself is firmly attached to the superior branch of the dorsal brain lobe (Fig. 1, 2E, and 4B, C). A thick TLIR and FLIR nerve of cerebral organ extends from the most posterior part of the dorsal lobe neuropile and penetrates the neuroglandular portion of the cerebral organ (con, Fig. 4C). We detected a few FLIR and much more numerous $C h A T^{+}$cells in the neuroglandular portion of the organ (arrowhead, Fig. 4C and arrow, Fig. 4B, respectively), while serotonin-like immunoreactivity was not detected (data not shown).

To gain further insight into the morphology of the cerebral organs, we supplemented the afore-mentioned confocal laser scanning microscopy (CLSM) based methods with ultrathin sectioning of resin-embedded specimens ( 60 days old juveniles) and TEM examination of the organ. That allowed us to describe the fine structure of the cerebral organ and ultrastructure of the particular cell types contributing to it. Since all detected cell types correspond directly 
to the ones described previously by Ling in his investigation of adult L. ruber [30], we adopted the terminology used therein.
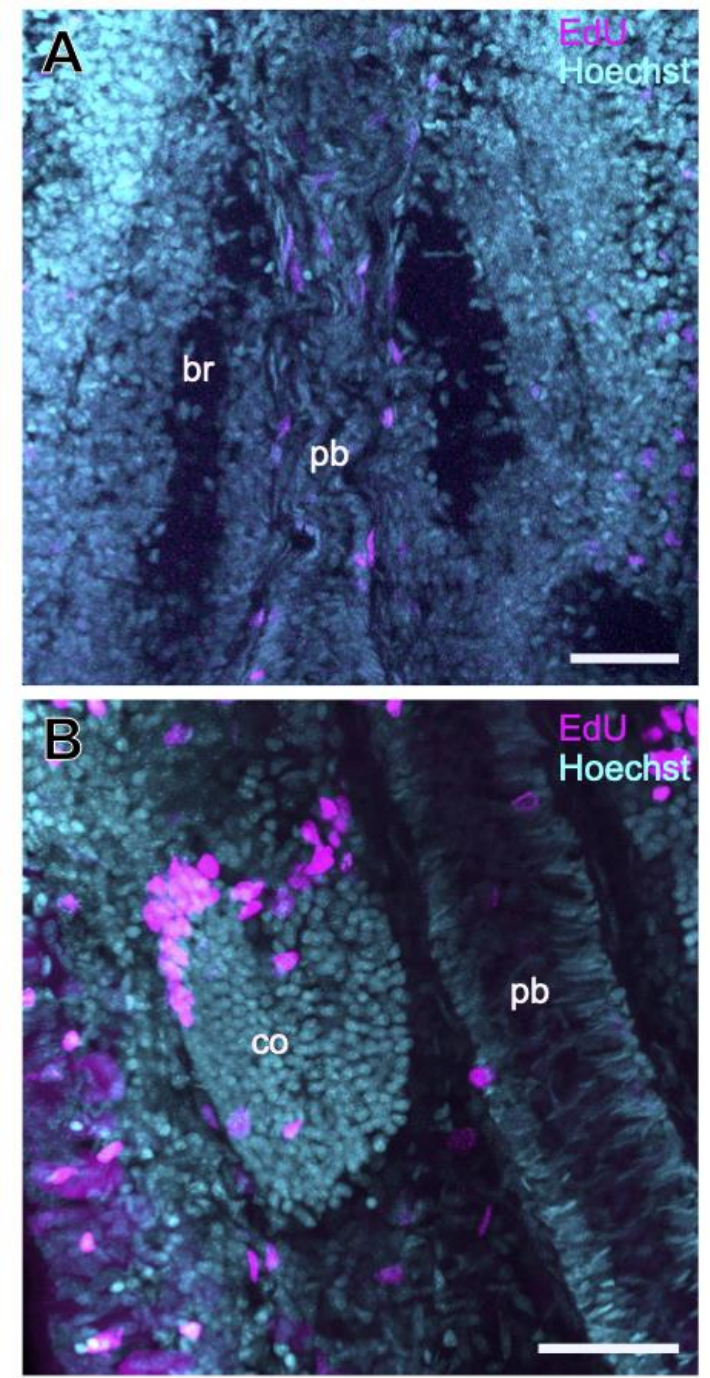

Fig. 3. Proliferating cells in the head of 60 days old juveniles of $L$. ruber visualized by incorporation of EdU (magenta), counterstained with nuclear marker Hoechst (cyan). Dorso-ventral Z-projections of brain region $(\mathbf{A})$ and cerebral organ $(\mathbf{B})$, with anterior to the top. Scale bars $25 \mu \mathrm{m}$. Abbreviations: $b r$ brain, co cerebral organ, $p b$ proboscis.

We investigated cross-sections through the neuroglandular portion of the cephalic organ. The mass of the organ is located between the proboscis and the lateral nerve cords (Fig. 4A) and it is penetrated by both the cerebral organ nerve (con) and the ciliated canal (cc). The ciliated canal is divided into two parallel parts: a larger major ciliated canal $(m j c)$ and a smaller minor ciliated canal (mnc) (Fig. 4G). Based on the ultrastructure, six distinct cell types can be distinguished in the sectioned area of the cerebral organ. The most numerous are type 1 bipolar cells (bc1), which constitute the majority of the cells in the neuroglandular mass (Fig. 4D, E). Their relatively small nuclei are roughly polygonal in cross-section and have dark 
nucleoplasm with the irregularly distributed chromatin (Fig. 4D). The very similar type 2 bipolar cells ( $b c 2)$ are much less frequent (Fig. 4E). They have the same nuclear size and shape as well as chromatin arrangement as $b c 1$, but their nucleoplasm is electron-translucent (Fig. $4 \mathrm{E})$. A relatively few ganglion cells $(g c)$ are present in the vicinity of the nerve of cerebral organ (Fig. 4D, E). Those cells have large nucleus that is almost circular in section and displays an electron-translucent nucleoplasm with nucleolus and irregularly distributed chromatin (Fig. 4D). On the dorsolateral side of the cerebral organ a single, large, irregularly shaped cell has been identified as neuroglandular cell (ngc, Fig. 4D-F). Its branching, spacious cytoplasm is filled with numerous electron-dense inclusions. Additionally, the Golgi apparatus was observed in the cytoplasm ( $g a$; inset, Fig. 4F). A single neuroglial cell ( $n g$ ) was observed on the opposite, ventro-median side of the organ (Fig. 4E). It is less voluminous than the neuroglandular cell, has a darker cytoplasm and more densely packed inclusions. A structure interpreted as a neuroglial axon is visible ca. $3 \mu \mathrm{m}$ from the neuroglial cell body (ax; inset, Fig. $4 \mathrm{E})$. The cells of the ciliated canal ( $c c c)$ represent the last cell type visible on the examined cross section (Fig. 4D, E). The apical surface of those cells is densely packed with cilia, which are equipped with asymmetrically bifurcating ciliary rootlets (cr; inset, Fig. 4G). Numerous mitochondria are present just below the ciliary rootlets, while the lateral sides of the cells are connected apically by desmosomes ( $m t$ and $d s$, respectively; inset, Fig. $4 \mathrm{G}$ ). The cilia on the border of the major and the minor canals (Icc) are characteristically dilated and form a septum that divides both canals (inset, Fig. 4G). Those cilia indicate the presence of the seventh cell type, lappet cells, although the cells themselves could not be told apart from the other cells of the ciliated canal.

EdU staining of mitotically active cells in the 60 days old juveniles indicted intensive proliferation in cerebral organs, especially in its anterior region (Fig. 3B). 


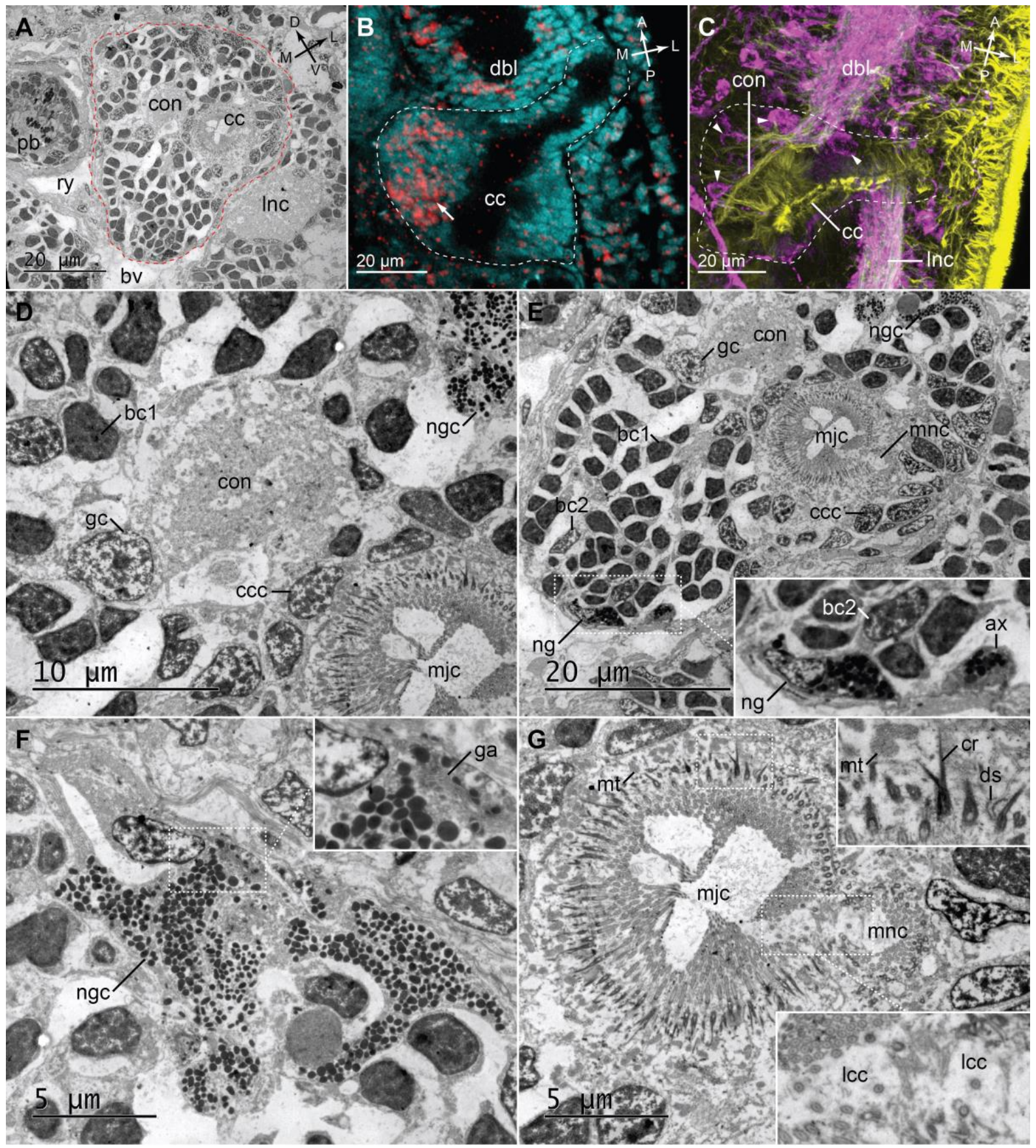

Fig. 4. Detailed morphology of cerebral organs in juveniles of L. ruber. TEM micrographs of cerebral organs in 60 days old juvenile, showing cross section $(\mathbf{A})$ and details of particular regions of the organ (D-G). Z-projections of cerebral organs in 42-days old juveniles visualized with Sytox green nuclear staining and in situ hybridization with probe against ChAT (cyan and red, respectively; B) and antibodies against FMRF-amide and tyrosinated tubulin (magenta and yellow, respectively; C). Cerebral organs are outlined in red $(\mathbf{A})$ and white $(\mathbf{B}, \mathbf{C})$. Orientation inside the animal is indicated in the top-right corners in panels $\mathbf{A}-\mathbf{C}$ ( $A$, anterior; $P$, posterior; $D$, dorsal; $V$, ventral; $M$, median; $L$, lateral). Micrographs in panels $\mathbf{D}-\mathbf{G}$, show magnified areas of panel $\mathbf{A}$. White outlined boxes on panels $\mathbf{E}, \mathbf{F}, \mathbf{G}$ indicates areas magnified in corresponding insets. Abbreviations: ax neuroglia axon, bc1 bipolar cell type1, bc2 bipolar cell type 2, bv blood vessel, $c c$ ciliated canal, $c c c$ ciliated canal cell, con nerve of cerebral organ, $c r$ 
ciliary rootlet, $d b /$ dorsal brain lobe, $d s$ desmosome, ga Golgi apparatus, gc ganglion cell, Icc dilated cilia of lappet cell, Inc longitudinal nerve cord, mjc major ciliated canal, mnc minor ciliated canal, $m t$ mitochondrium, ng neuroglia, ngc neuroglandular cell, pb proboscis, ry rhynchocoel. White arrow indicates $\mathrm{ChAT}^{+}$cells in cerebral organ, white arrowhead FMRF-amide-like immunoreactivity in cerebral organ.

Gene expression in the head

We investigated expression of 12 transcription factors (TFs), which have a role in CNS development of many bilaterians. Those genes include the conserved general brain markers (otx, bf1), genes involved in brain regional specification (pax6, nk2.1, nk2.2, rx, otp) and other neural genes, which are co-expressed in the annelid mushroom bodies (dach, emx, arx, svp, $t / l)$.

Expression of otx has been previously described for earlier developmental stages of L. ruber, in which the gene has a general anterior expression in the head [40]. In the 42 days old juveniles, which we investigated, the gene otx is predominantly expressed in the brain (Fig. $5 \mathrm{~A}$ and $\mathrm{B}$ ) and cerebral organs (Figs. $5 \mathrm{~A}, 6 \mathrm{~B}$ ). In the brain, otx is broadly and uniformly expressed both in dorsal and ventral lobes (Fig. 5A and B). In the cerebral organs it is also widely expressed, both in the ciliated canal and neuroglandular part (Fig. 6B). A similar expression pattern of otx in the brain and cerebral organs has been also reported from developing juveniles of closely related Lineus viridis [52].

bf1 is expressed in the brain, cerebral organs, scattered cells in the anterior epidermis and in the rhynchocoel (Figs. $5 C$ and $D, 6 C$ ). In the brain bf1 is broadly expressed in the dorsal lobe (Fig. 5C), but in the ventral one it is only detectable in the lateral clusters of cells (Fig. 5D). The detected expression of $b f 1$ in the cerebral organ is very strong in the neuroglandular part, whereas we did not detect a signal in the ciliated canal (Fig. 6C). 


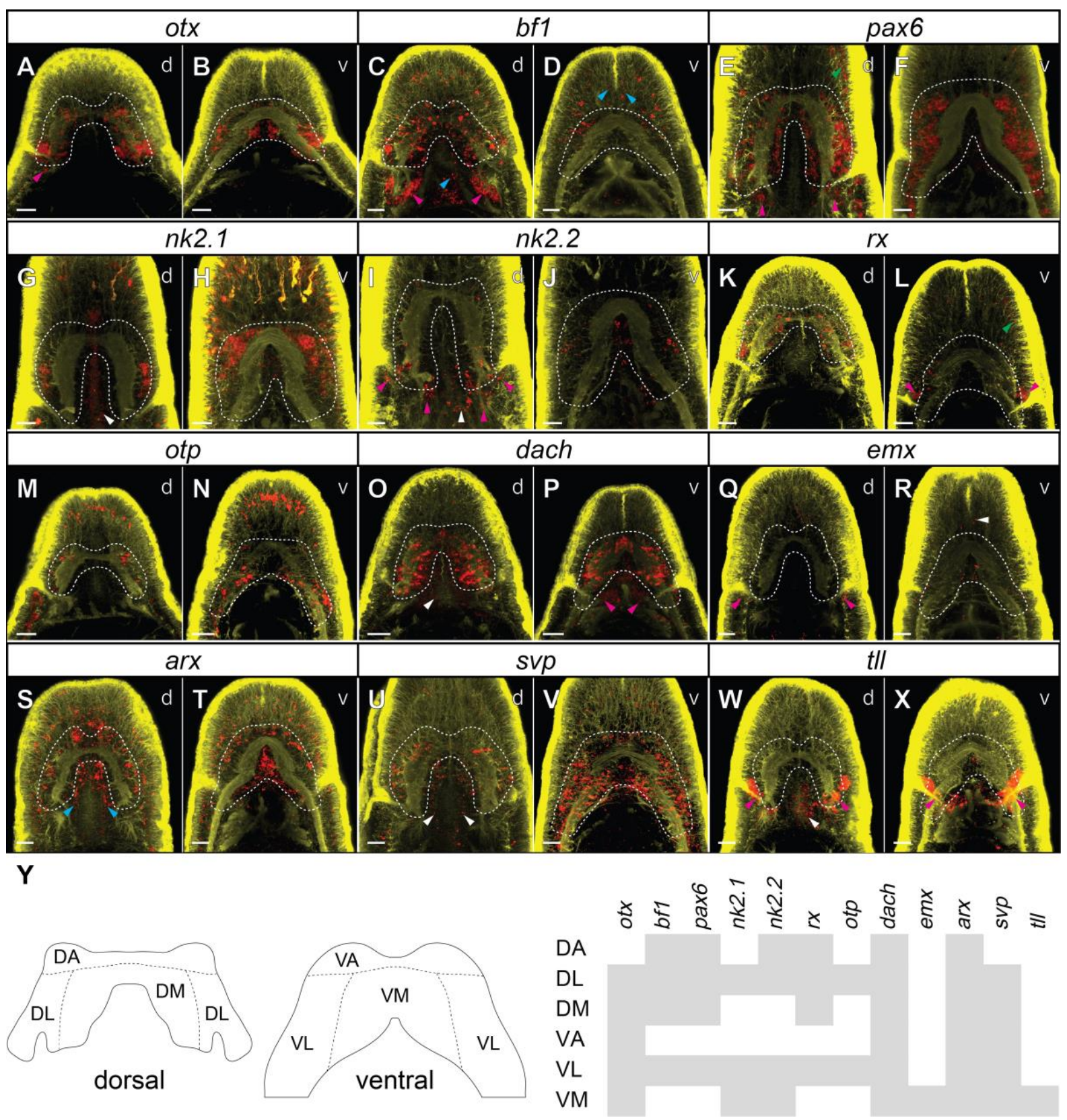

Fig. 5. Expression of investigated transcription factors in the heads of 42 days old juveniles of $L$. ruber. A-X fluorescent in situ RNA hybridization, for each panel the name of the hybridized gene is shown in the white box above the micrographs. Fluorescent signal from RNA probes is in red, from antibody staining against tyrosinated tubulin in yellow and brain lobes are outlined in white. All animals are shown in dorso-ventral projection with anterior to the top; the letter in the top-right corner of each panel indicates whether focus is on dorsal $(d)$ or ventral $(v)$ structures. Detailed expression patterns are described in the text. Magenta arrowheads indicate expression in the cerebral organs, blue in the rhynchocoel, green in the lateral cephalic slits, white in the proboscis. Scale bars $20 \mu \mathrm{m}$. Y map of gene expression in the $L$. ruber brain. Grey bars indicate that gene is expressed in a particular brain region. Abbreviations: $D A$ dorso-anterior brain domain, $D L$ dorso-lateral brain domain, $D M$ dorso-median brain domain, $V A$ ventro-anterior brain domain, $V L$ ventro-lateral brain domain, $V M$ ventro-median brain domain. 
Expression of pax6, $n k 2.1$ and $n k 2.2$ has been previously investigated in the juveniles of L. ruber in relation to the nerve cord patterning [39], however, the expression of those three genes in the brain was not described in the details that we provide here. In the head region, pax6 is expressed in the brain, the epidermal cells of the lateral cephalic slits and in the cerebral organs (Figs. 5E and F, 6D). The gene is broadly expressed in the dorsal lobes (Fig. $5 \mathrm{E})$, while in the ventral ones its expression is restricted to the lateral portions of the brain (Fig. 5F). In the cerebral organs the gene is expressed in the stripe of cells on the lateral side of the neuroglandular portion (Fig. 6D).

In the head region, $n k 2.1$ is expressed in the brain and proboscis (Fig. $5 \mathrm{G}$ and $\mathrm{H}$ ). In the dorsal lobes the gene is expressed only in the small lateral clusters of cells (Fig. 5G), while on the ventral side the gene is broadly expressed both in the median and lateral domains (Fig. $5 \mathrm{H}$ ). $n k 2.1$ is not expressed in the cerebral organs.

$n k 2.2$ is expressed in the brain, proboscis and cerebral organs (Fig. $5 \mathrm{I}$ and J). In the dorsal brain lobes, the gene is expressed in large clusters of posterior cells and in scattered anterior domains (Fig. 5I), whereas ventrally, it is expressed in median and lateral cell clusters (Fig 5J). Expression in the cerebral organs is detected in isolated domains of both ciliated canal and neuroglandular portion (Fig. 5I).

The gene $r x$ is expressed in the brain, anterior sensory organs, epidermal cells of lateral cephalic slits and in the cerebral organs (Figs. 5K and L, 6E). Dorsally, the gene is expressed in isolated cells distributed relatively uniformly throughout the brain lobes (Fig. 5K). In the ventral lobes, $r x$ is expressed only in a pair of postero-lateral cell clusters (Fig. 5L). In the cerebral organs, the gene is specifically expressed in the cluster of epidermal cells at the anterior side of the ciliated canal opening (Fig. 6E). 

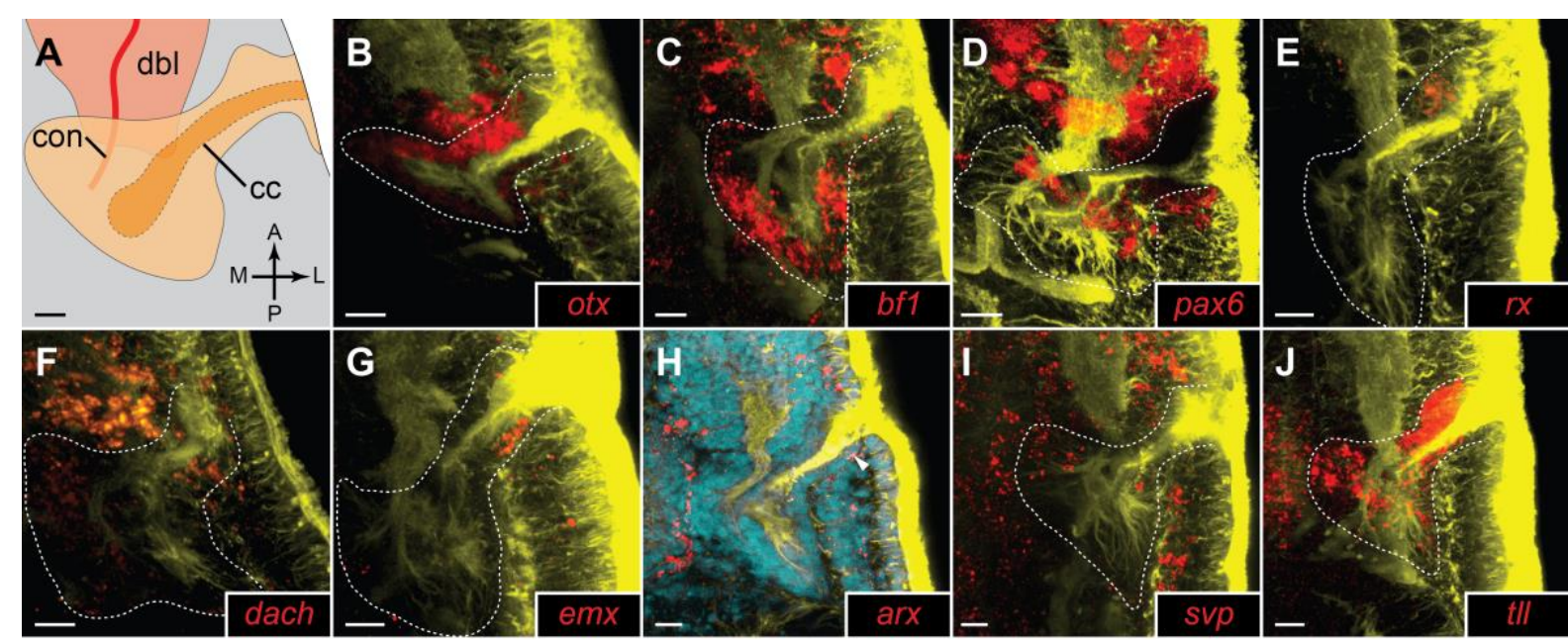

Fig. 6. Details of gene expression in the cerebral organs of 42 days old juveniles of $L$. ruber. A schematic drawing of the cerebral organ and accompanying neural structures, orientation in the animal is indicated in bottom-right corner ( $A$, anterior; $P$, posterior; $M$, median; $L$, lateral). Abbreviations: cc ciliated canal, con nerve of cerebral organ, $d b /$ dorsal brain lobe. B-J fluorescent in situ RNA hybridization, for each panel the name of hybridized gene is provided in the bottom-right corner. Fluorescent signal from RNA probes is in red, from antibody staining against tyrosinated tubulin in yellow and from Sytox green nuclear staining in cyan; cerebral organs are outlined in white. The detailed expression patterns are described in the text. White arrowhead indicates $a r x^{+}$cell at the posterior side of the ciliated canal opening. Scale bars $10 \mu \mathrm{m}$.

Expression of otp is detectable in the brain, LNCs, and numerous anterior sensory cells (Fig.

$5 \mathrm{M}$ and $\mathrm{N}$ ). In the dorsal lobes, the gene is expressed only in a relatively few lateral cells (Fig. $5 \mathrm{M})$, while ventrally it is also predominantly expressed in the lateral cells of the brain lobes, but its expression was also detected in the more median cells contributing to the mouth innervation and anterior part of the LNC (Fig. 5N).

In the head region, the gene dach is expressed in the brain, cerebral organs, proboscis and few isolated anterior cells (Figs. 50 and P, 6F). The expression in the brain is rather uniform and transcripts of the gene were detected in all regions of both dorsal and ventral lobes (Fig. 50 and $\mathrm{P}$ ). In the cerebral organs, the gene was detected in some of the cells of both the ciliated canals and the neuroglandular portion (Fig. 6F). 
Expression of the gene emx was detected in the brain, cerebral organs, proboscis, and cells along anterior cephalic nerves (Figs. $5 Q$ and $R, 6 G$ ). In the brain the gene is expressed only in a few cells in the ventro-median domain (Fig. 5R). In the cerebral organs the gene transcripts were detected in the cells at the posterior side of the ciliated canal opening and in a single median cell in the neuroglandular part of the organ (Fig. 6G).

The TF arx has a broad expression in the anterior body of the juvenile L. ruber. It is expressed in the brain, rhynchocoel, epidermal cells, anterior sensory cells and in the cerebral organs (Figs. $5 \mathrm{~S}$ and $\mathrm{T}, 6 \mathrm{H}$ ). In both dorsal and ventral brain lobes, its expression was detected in numerous anterior, lateral and median cells (Figs. $5 \mathrm{~S}$ and $\mathrm{T}$ ). In contrast, the expression in the cerebral organs was restricted to a single cell at the posterior side of the ciliated canal opening (Fig. 6H).

The gene svp is also broadly expressed in anterior structures; its expression was detected in the brain, cerebral organs, LNCs, anterior sensory cells and proboscis (Figs. $5 \mathrm{U}$ and V, 6I). In the dorsal brain lobes, it is expressed in cells distributed through the lateral and median regions (Fig. 5U), while ventrally it is expressed uniformly in the entire ventral lobes (Fig. 5V). In the cerebral organs, expression of svp was detected in some anterior and lateral cells of the neuroglandular part (Fig. 6I).

Transcripts of the gene $t / l$ were detected in the brain, cerebral organs and proboscis (Figs. 5W and $X, 6 J)$. Expression in the brain was restricted just to a few cells posteriorly to the ventral commissure (Fig. 5X). Signal from the probes against $t / l$ was extremely strong in the cerebral organs (Fig. 5W and X) and was observed throughout the entire structure in cells of both the ciliated canal and the neuroglandular portion (Fig. 6J).

The brain of the juvenile $L$. ruber is divided by commissures and lobe neuropiles into eight regions: unpaired dorso-anterior, dorso-median, ventro-anterior and ventro-median regions 
as well as paired dorso-lateral and ventro-lateral areas (Fig. 5Y). Mapping of the abovedescribed gene expression patterns onto those brain domains reveled that most of the regions express unique combination of the TFs (Fig. 5Y). The only brain regions which seem to express the same sets of TFs are dorsal and ventral lateral domains (Fig. 5Y).

\section{Gene co-expression during brain development}

To further explore co-expression of some of the TFs in the brain, we performed double in situ hybridization of the selected brain patterning genes (nk2.1, nk2.2, pax6 and $r x)$. In addition to the investigation of 42 days old juveniles, we also examined co-expression of those genes in the earlier developmental stage, 25 days old early juveniles, in order to test whether the observed co-expression patterns are conserved throughout ontogenesis.

The CNS of 25 days old juveniles shows much simpler morphology when compared to the hatched juveniles (Fig. 7A). It is composed of LNCs, which merge anteriorly in the brain with two commissures - a thicker ventral and thinner dorsal - that form a ring shaped neuropile around the developing proboscis rudiment. At this developmental stage, the brain is not yet divided into the dorsal and ventral lobes and the cerebral organs are not fully formed, being mainly composed by the ciliated canal, that is not directly connected with the brain [40].

In the brain of 25 days old juvenile, $n k 2.1$ is expressed along the ventral commissure and in the lateral parts of the brain (Fig. 7B, C, E, G). In its lateral domains the gene is co-expressed with pax6 (blue arrowheads, Fig. 7B and C) and $r x$ (blue arrowheads, Fig. 7G). Additionally, some of the lateral $n k 2.1^{+}$cells also express $n k 2.2$ (blue arrowheads, Fig. 7E). The more median $n k 2.1^{+}$cells that are associated with the ventral commissure are devoid of pax6, $n k 2.2$ and $r x$ expression (white arrowheads, Fig. 7C, E, G). In addition to the expression in lateral 
domains, pax6, $n k 2.2$ and $r x$ are also expressed in cells associated with the dorsal commissure,

which do not co-express $n k 2.1$ (white arrowheads, Fig. 7B, D, F).

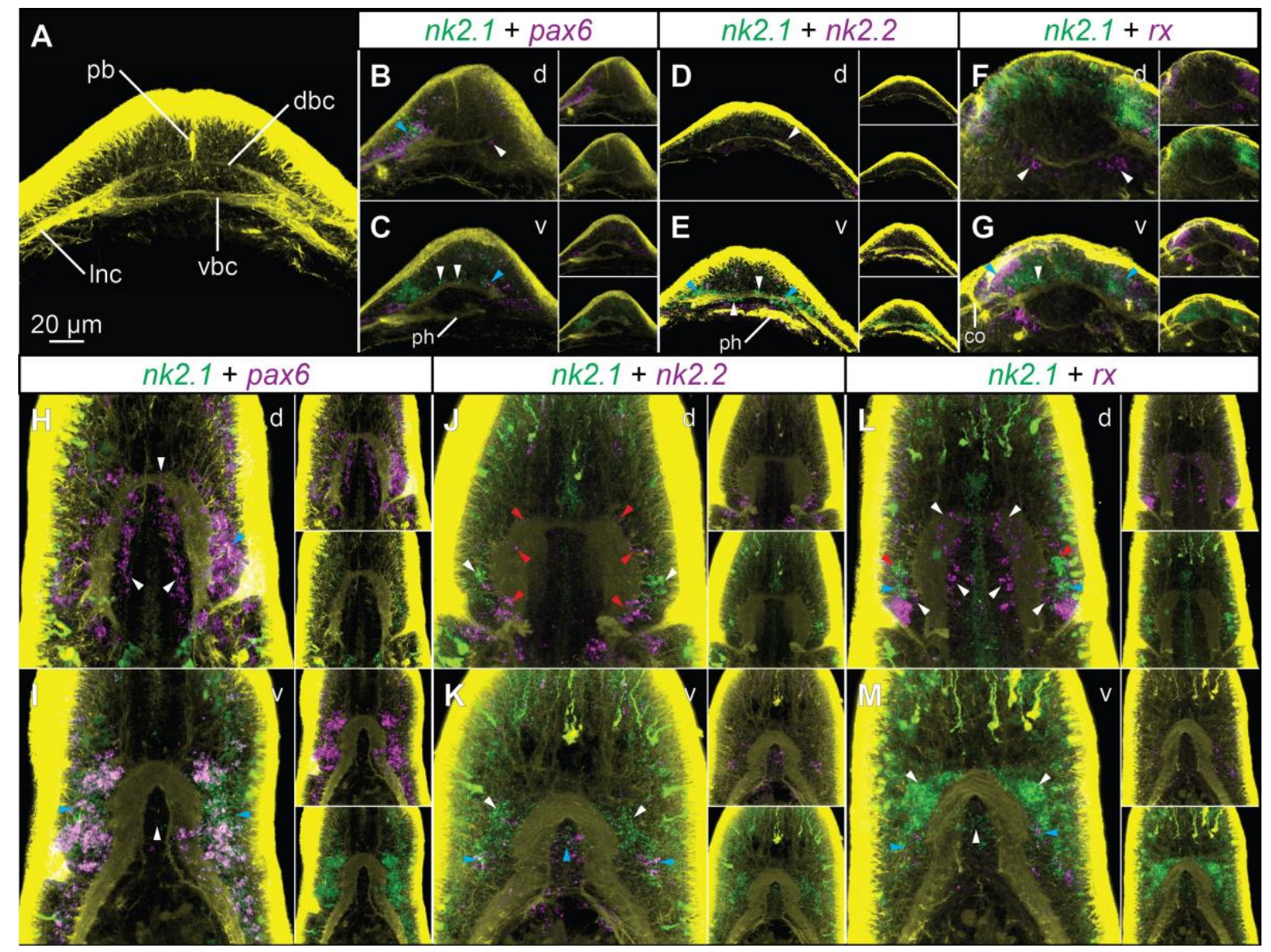

Fig. 7. Co-expression of brain patterning genes in the developing brain of $L$. ruber. A morphology of the brain in 25 days old juveniles. $\mathbf{B}-\mathbf{G}$ co-expression in the brain of 25-days old juveniles. $\mathbf{H}-\mathbf{M}$ coexpression in the brain of 42-days old juveniles. For each panel the color-coded names of hybridized genes are shown in the white box above the micrographs. White and red arrowheads indicate exclusive expression of one of the hybridized genes, blue arrowheads indicate co-expression. All animals are shown in dorso-ventral projection with anterior to the top; the letter in the top-right corner of each panel indicates whether the focus is on dorsal $(d)$ or ventral $(v)$ structures. Micrographs on panels $\mathbf{B}-\mathbf{M}$ are not to the scale. Abbreviations: co cerebral organ, $d b c$ dorsal brain commissure, Inc lateral nerve cord, $p b$ proboscis rudiment, ph pharynx.

The analysis of gene co-expression in the 42 days old juveniles generally corroborates the expression map based on single gene hybridization, however it allows more detailed description of the brain molecular regionalization. In the dorsal brain pax6 is broadly 
expressed in the lateral and median domains (white arrowheads, Fig. $7 \mathrm{H}$ ) and only small clusters of lateral cells co-express pax6 and nk2.1 (blue arrowhead, Fig. $7 \mathrm{H}$ ). In the ventral lobes, the lateral cells co-express pax6 and $n k 2.1$ (blue arrowheads, Fig. 7l), while cells in the median domain express only $n k 2.1$ (white arrowhead, Fig. 7l). $n k 2.1$ and $n k 2.2$ are not coexpressed in the dorsal brain (Fig. 7J). $n k 2.1$ is expressed in the most lateral cells of the dorsal brain (white arrowheads, Fig. 7J), while $n k 2.2$ is expressed in the large, more posterior domains and in scattered cells in the anterior brain region (red arrowheads, Fig. 7J). In the ventral brain, both genes are co-expressed in the postero-lateral and median domains (blue arrowheads, Fig. 7K), however $n k 2.1$ has much broader ventral expression with many $n k 2.1^{+}$ cells devoid of $n k 2.2$ expression (white arrowheads, Fig. 7K). $r x$ is expressed in scattered anterior, median and lateral cells in the dorsal brain, which do not co-express $n k 2.1$ (white arrowheads, Fig. 7L). In the lateral parts of the brain some cells co-express $r x$ and $n k 2.1$ (blue arrowheads, Fig. $7 \mathrm{~L}$ ), while some $n k 2.1^{+}$cells do not express $r x$ (red arrowheads, Fig. $7 \mathrm{~L}$ ). In the ventral brain the antero-lateral and median $n k 2.1^{+}$cells do not express $r x$ (white arrowheads, Fig. 7M), while small clusters of postero-lateral cells co-express both genes (blue arrowheads, Fig. 7M).

On the whole, comparison of gene co-expression between 25- and 42-days old juveniles shows that the general molecular patterning of the developing brain is retained throughout development. The ventro-median region expresses $n k 2.1$ but not pax 6 nor $r x$. The lateral brain includes cells co-expressing $n k 2.1$ with pax6, $n k 2.2$ and $r x$, while dorsal brain is mainly composed of $p a x 6, n k 2.2$ and $r x$ positive cells which do not co-express $n k 2.1$. The differences between both life stages are primarily associated with the more complex architecture of the brain in 42 days old juveniles, which requires a more intricate developmental control, nevertheless the most general gene expression patterns are conserved. 


\section{Discussion}

\section{Comparison of juvenile and adult morphology}

Nervous system has been investigated in great detail in adult Lineus ruber [20, 22-26, 29-31] and Lineus viridis $[19,20,24,25]$, a morphologically similar species that belongs to the same species complex $[53,54]$. Comparison between the juvenile and adult worms reveals that all major nervous structures described in the adults are already present in the 42 days old juveniles, indicating that at this stage the general neuroarchitecture is already fully formed and that further development is mostly related with increase in the size but not morphological complexity. The same pattern is observed in number and diversity of cell types contributing to the cerebral organs. There are, however, some minor differences in immunoreactivity patterns between both life stages. For instance, SLIR perikarya have been reported in the dorsal brain ganglia of adult L. ruber [23], while we observed immunoreactivity against serotonin only in the ventral brain ganglia of the juveniles (Fig. 2I). This indicates, that even though the general morphology of the brain is already established at the moment of hatching, the following growth of the brain is not purely quantitative, but also new cell types are added in some brain regions during further development. Moreover, staining of mitotically active cells showed that in 60 days old juveniles cell proliferation in the brain is lower than in the other organs, while the cells of the cerebral organs are still intensively dividing (Fig. 3), indicating allometric growth of the CNS.

The major postpharyngeal commissure, which ventrally connects the lateral nerve cords, is the only juvenile neural structure which does not correspond directly to any of the elements of the adult nervous system of $L$. ruber $[20,22,29]$ or, to our best knowledge, of any other nemertean, which nervous system has been studied thus far [e.g. 17-19, 20, 21, 28, 55-58]. In adult nemerteans, the lateral nerve cords are connected by numerous delicate ventral 
commissures, that are composed just of bundles of neurites and are considered as part of the peripheral nervous system. Conversely, the postpharyngeal commissure described in this study is associated with few SLIR and numerous $C h A T^{+}$perikarya and has typical medullary arrangement, markedly different from the remaining ventral commissures (Figs. 1 and 2). There are two possibilities to explain this discrepancy in morphology of both stages: either the commissure degenerates during ontogeny or, due to the allometric growth, becomes much less prominent in later developmental stages and was overlooked in previous investigations.

Nevertheless, the observation of the postpharyngeal ventral commissure in a nemertean is interesting since similar structures are present in numerous annelids (e.g. the first commissure connecting ventral nerve cords [59-64]), as well as in all major clades of gastrotrichs [65-67] and gnathiferans [68-71]. Therefore, the distribution of this character on the phylogenetic tree raises the possibility that the ventral postpharyngeal commissure connecting the major nerve cords might represent a plesiomorphic spiralian trait retained in some form in numerous clades.

\section{Expression of brain patterning genes in Spiralia}

Molecular patterning of the brain has been investigated in relatively many spiralians, representing diverse clades with broad spectrum of morphological complexity of their brains (Tab. 1). Among those species, the best studied is the annelid Platynereis dumerilii, which possesses a relatively complex brain with multiple morphologically, functionally and developmentally distinct regions [42, 49, 72-74]. One of the important characteristics of gene expression patterns during the development of the $P$. dumerilii brain is regional restriction of $n k 2.1$ expression to the ventro-median region and pax6 expression in the lateral domains 
(including eyes and mushroom bodies), with only the minimal overlap of expression of both genes (Fig. 8A; $[42,49]$ ). This expression pattern resembles the one observed in vertebrates $[75,76]$ and has been proposed as an ancestral bilaterian trait [42]. Although a comparable expression of those two genes is also witnessed in some Spiralia (Tab. 1), including other annelids $[43,47,48]$, rotifers [39] and brachiopods [39, 46, 77-79], we did not retrieve a similar pattern in neither 25- nor 42-days old juveniles of L. ruber (Figs. 7B, C, H, I and 8B). $n k 2.1$ is indeed mostly expressed in the ventral domain (Figs. $5 \mathrm{H}, 8 \mathrm{~B}$ ), however, it is broadly co-expressed with pax6 in the ventral lobes and in the small dorso-lateral domains (Figs. $7 \mathrm{H}$, J, 8B); while pax6 shows expression not only in the lateral domains but is generally broadly expressed throughout the entire brain (including the dorso-median domain), with the only exception of the small ventro-median region (Figs. 5E, F, 8B). A very similar expression of $n k 2.1$ and pax6 has been observed in planarians, where $n k 2.1$ is expressed mostly in the ventral portion of the brain $[44,45]$, while one of the pax 6 paralogs, pax6A, is broadly expressed in the brain tissue $[44,80]$. A further parallel between planarians and Lineus is associated with a seemingly diminished role of pax6 in eye formation: pax6 is not expressed during eye development neither in L. ruber (this study) nor in L. viridis [81] (although it seems to have a role in eye regeneration in L. sanguisues [81]), while in flatworms eye regeneration has been demonstrated to be pax6 independent [80]. The role of pax6 in eye patterning is otherwise highly conserved among bilaterians [e.g. $82,83,84]$. Due to the unstable position of Nemertea on the spiralian phylogeny [e.g. 6-8, 10], it is currently impossible to determine whether those similarities between platyhelminths and nemerteans are due to the convergent evolution, a common evolutionary innovation or retention of ancestral plesiomorphic conditions in both lineages. 
Table 1. Expression of the selected genes in the spiralian brains.

\begin{tabular}{|c|c|c|c|c|c|c|c|c|c|c|}
\hline \multirow[t]{2}{*}{ Species } & \multirow[t]{2}{*}{ Clade } & \multirow[t]{2}{*}{ Brain type } & \multicolumn{8}{|c|}{ Gene expression in the brain } \\
\hline & & & pax6 & ref & $n k 2.1$ & ref & $n k 2.2$ & ref & $r x$ & ref \\
\hline Lineus ruber & Nemertea & complex & $\begin{array}{l}\text { broadly expressed } \\
\text { with the exception } \\
\text { of ventro-median } \\
\text { domain }\end{array}$ & this study & $\begin{array}{l}\text { ventral brain, dorso-lateral } \\
\text { domains }\end{array}$ & this study & $\begin{array}{l}\text { scattered expression in } \\
\text { ventral, dorso-lateral and } \\
\text { dorso-posterior domains }\end{array}$ & this study & $\begin{array}{l}\text { dorsal brain, } \\
\text { ventro-lateral } \\
\text { domains }\end{array}$ & this study \\
\hline $\begin{array}{l}\text { Platynereis } \\
\text { dumerilii }\end{array}$ & Annelida & complex & $\begin{array}{l}\text { paired lateral } \\
\text { domains }\end{array}$ & {$[42,49]$} & ventro-median domain & {$[42,49]$} & no expression in the brain & {$[41]$} & anterior brain & {$[42]$} \\
\hline $\begin{array}{l}\text { Dimorphilus } \\
\text { gyrociliatus }\end{array}$ & Annelida & compact & $\begin{array}{l}\text { paired lateral } \\
\text { domains }\end{array}$ & [43] & $\begin{array}{l}\text { ventro-median and medio- } \\
\text { lateral domains }\end{array}$ & {$[43]$} & no expression in the brain & [43] & N/A & \\
\hline Capitella teleta & Annelida & compact & $\begin{array}{l}\text { paired lateral } \\
\text { domains }\end{array}$ & [48] & $\begin{array}{l}n k 2.1 a: \text { paired medio- } \\
\text { lateral domains } \\
n k 2.1 b: \text { paired medio-later } \\
\text { domains }\end{array}$ & {$[47]$} & $\mathrm{N} / \mathrm{A}$ & & N/A & \\
\hline $\begin{array}{l}\text { Terebratalia } \\
\text { transversa }\end{array}$ & Brachiopoda & $\begin{array}{l}\text { larval apical } \\
\text { organ }\end{array}$ & $\begin{array}{l}\text { paired dorso-lateral } \\
\text { domains }\end{array}$ & {$[77,79]$} & ventral domain & {$[46,78]$} & $\begin{array}{l}\text { no expression in the apical } \\
\text { organ }\end{array}$ & [39] & $\mathrm{N} / \mathrm{A}$ & \\
\hline $\begin{array}{l}\text { Novocrania } \\
\text { anomala }\end{array}$ & Brachiopoda & $\begin{array}{l}\text { larval apical } \\
\text { organ }\end{array}$ & $\begin{array}{l}\text { dorso-lateral } \\
\text { domain }\end{array}$ & [79] & ventral domain & [78] & $\begin{array}{l}\text { no expression in the apical } \\
\text { organ }\end{array}$ & [39] & $\mathrm{N} / \mathrm{A}$ & \\
\hline $\begin{array}{l}\text { Phoronopsis } \\
\text { harmeri }\end{array}$ & Phoronida & $\begin{array}{l}\text { larval apical } \\
\text { organ }\end{array}$ & $\begin{array}{l}\text { no expression in } \\
\text { the apical organ }\end{array}$ & {$[85]$} & $\begin{array}{l}\text { no expression in the apical } \\
\text { organ }\end{array}$ & {$[86]$} & N/A & & N/A & \\
\hline $\begin{array}{l}\text { Schmidtea } \\
\text { mediterranea }\end{array}$ & Platyhelminthes & compact & $\begin{array}{l}\text { pax6A: broadly } \\
\text { expressed } \\
\text { throughout the } \\
\text { brain } \\
\text { pax6B: lateral brain }\end{array}$ & {$[44]$} & $\begin{array}{l}\text { ventral brain, dorso- } \\
\text { median domains }\end{array}$ & {$[45]$} & no expression in the brain & [87] & $\mathrm{N} / \mathrm{A}$ & \\
\hline $\begin{array}{l}\text { Epiphanes } \\
\text { senta }\end{array}$ & Rotifera & compact & $\begin{array}{l}\text { paired lateral } \\
\text { domains }\end{array}$ & [39] & $\begin{array}{l}n k 2.1 a: \text { dorso-median } \\
\text { domain } \\
n k 2.1 b: \text { median domain } \\
n k 2.1 c: \text { vento-median } \\
\text { domain }\end{array}$ & [39] & paired lateral domains & [39] & $\mathrm{N} / \mathrm{A}$ & \\
\hline
\end{tabular}




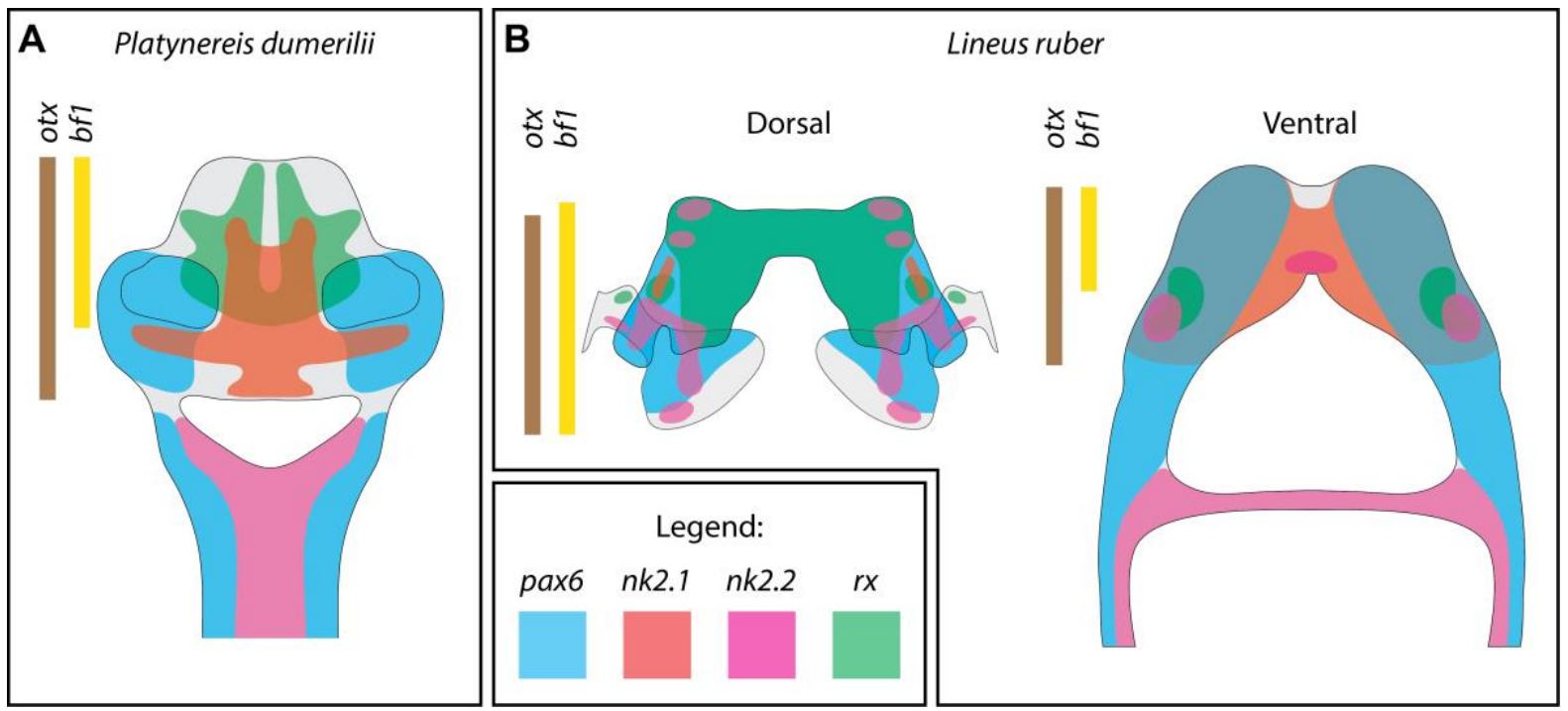

Fig. 8. Comparison of gene expression in the CNS of $(\mathbf{A})$ annelid Platynereis dumerilii (based on results from [41, 42, 49]) and (B) nemertean Lineus ruber (based on current study and [39]).

Another important differences in expression of brain patterning genes between L. ruber and other Spiralia includes the expression of $n k 2.2$ within numerous brain domains of $L$. ruber (while the gene lacks brain expression not only in annelids $[41,43]$, but also in brachiopods [39] and flatworms [87]) as well as broad expression of $r x$ in the dorsal lobes of the nemertean brain (versus their more rostral expression in P. dumerilii $[42,49])$. Altogether this comparison shows that complex brains of nemerteans, and especially their dorsal lobes, show little resemblance in the molecular patterning to the complex brains of $P$. dumerilii (Fig. 8), which in turns seem to share more molecular similarities with simpler brains of other annelids and apical organs of brachiopod larvae (Tab. 1). This observation, in concert with morphological data $[21,64,88]$, indicates that complex brains of nemerteans and errant annelids evolved convergently, due to e.g. similar selective pressure associated with predatory/active life style [89]. We propose that the increase in the brain size and complexity in those two lineages was achieved by independent expansions of non-homologous regions of simpler brains present in their respective ancestors. 
Some of the investigated nemertean brain patterning genes are also expressed in the proboscis (nk2.1, nk2.2, dach, svp, tIl) and rhynchocoel (bf1, arx), two morphological apomorphies of Nemertea $[15,16]$. Taking into account that the proboscis is a highly innervated structure [this study; also 15-20, 22, 23, 25, 26, 29, 57, 58, 90], the neuronal genes in the proboscis might be expressed in the developing neuronal network of the organ. Comparable results were obtained by body region-specific transcriptomics of the nemertean Notospermus geniculatus, in which expression of some of the neuronal markers (e.g. elav, syt12) was also detected in the proboscis [91]. Expression of arx and bf1 in the rhynchocoel, a coelom derived structure $[16,92]$, seems more peculiar, since those genes have a generally conserved neuroectodermal expression in Bilateria [46, 93-97]. However, arx is also expressed in clade-specific morphological structures of brachiopods (in chaetal sacs and protegulum forming epithelium [98, 99]), annelids (in chaetal sacs [100]) and mollusks (in radula formative tissue [101]). Therefore, our data just further expand the list of potential cooptions of arx into patterning of spiralian evolutionary novelties.

Are mushroom bodies and cerebral organs derived from the same ancestral organs?

In numerous annelid brains, morphologically distinct structures, referred to as mushroom bodies, are present, which have allegedly chemosensory and cognitive functions $[35,36,49$, 73, 102-107]. There is an ongoing discussion on whether those structures are part of the ancestral annelid body plan or whether they evolved more recently in one of the annelid subclades [35, 73, 108]. However, their phylogenetic distribution (especially the lack of comparable structures in Palaeoannelida and Sedentaria $[64,88,109])$ favors the latter option $[64,88,108,110]$ 
Nevertheless, morphologically similar structures are also present in Panarthropoda [36, 105, 111-114], which lead some authors to the idea that mushroom bodies-like structures were already present in the common protostome ancestor $[36,49,73,105]$. Although similarities in molecular patterning of annelid mushroom bodies and vertebrate pallium led to the assumption that both structures originated from the same sensory and associative brain center of hypothetical ancestral bilaterians [49], such homology statements, based on observation of only two phylogenetically distant clades, are always at the best case highly tentative $[89,115]$.

Cerebral organs of nemerteans, in contrast to the annelid mushroom bodies, can be unequivocally reconstructed as present in the last common nemertean ancestor $[20,22,28]$. However, it remains unresolved whether they are nemertean evolutionary novelty or rather homologs of the mushroom bodies of annelids $[19,35,36]$ or the lateral ciliated pits present in catenulids and macrostomids $[30,34,116,117]$, the two earliest sequentially branching platyhelminth clades [118]. Similarities between the mushroom bodies of annelids and the cerebral organs of nemerteans are rather superficial: the former are integral parts of the brain and are not connected to the external realm, while the latter are always contacting ambient environment and, especially in Hoplonemertea, might be spatially separated from the CNS $[17,28,32,33]$. On the other hand, the function, general morphology, connectivity and fine structure of cerebral organs of nemerteans and ciliated pits of flatworms bear a strong resemblance $[30,34,116,117]$, making their homology much more likely. Taking into account the arrangement of the cerebral organs in various nemertean clades, the "ciliated pit" organization seems to represent an ancestral character state also in nemerteans [19-21]. If one accepts that the cerebral organs of nemerteans and ciliated pits of catenulids and macrostomids are homologues [34], then, depending on the phylogenetic position of 
nemerteans, there are two possible scenarios of their evolution: 1) If nemerteans are sister group to platyhelminths (Parenchymia hypothesis $[7,119]$ ), then the ciliated pits-like structures represent a synapomorphy of Parenchymia. 2) On the other hand, if nemerteans are closer to annelids than flatworms $[5,6,8,10]$, then the presence of ciliated pits might represent a plesiomorphic condition, present also in the annelid ancestor.

In the face of the above-discussed concerns about the homology of mushroom bodies and cerebral organs, we were surprised to find that cells constituting the cerebral organs express the same set of transcription factors as mushroom bodies of annelids (with both structures being additionally free of $n k 2.1$ expression). Although all nine of the annelid mushroom body markers, which expression we tested, were expressed in the cerebral organs of L. ruber, they were not co-expressed uniformly throughout the entire structure. Some genes (otx, bf 1 , dach and $t / l)$ were expressed in all regions of the organ, while others were restricted only to some cells in the neuroglandular portion (pax6, emx, svp) or the ciliated canal (rx, emx, arx). The complicated landscape of TFs expression in L. ruber correlates well with the fact, that the cerebral organs of 60 days old juveniles are already composed of numerous diverse cell types, including neurons, glia cells, glandular cells and ciliated epidermal cells (Fig. 4) as well as still dividing, possibly not fully differentiated, cells (Fig. 3). Unfortunately, with the resolution of our data, we were not able to pinpoint co-expression of particular TFs with specific cell types contributing to the organ. In P. dumerilii these TFs are also not expressed uniformly in the entire mushroom body and show regionalized expression [49], however, their regionalization does not simply correspond to the one observed in the cerebral organs of L. ruber. For example, otx and $t / l$ are expressed only in the subset of neurons constituting mushroom body, while expression of pax6, arx and svp is detected in most of the cells forming the organ [49]. Therefore, even though the same set of genes is expressed in both types of organs, their exact 
co-expression in particular cell types is probably divergent and the apparent similarities in gene expression profiles between both organs might be more superficial than they appear on the first sight.

A further problem with the interpretation of the gene expression patterns in the cerebral organs is related to the fact that, both in annelid and in nemertean, it remains unknown whether those TFs interact in the same gene regulatory network (GRN) or whether they are independently expressed in different, unrelated cell types. If they are part of the same GRN, then co-option of the ancestral regulatory program into patterning of non-homologues structures might explain the observed similarities. If indeed the ciliated pits-like structures, homologues to the cerebral organs of nemerteans, were present in the annelid ancestor (see above) it is possible to envision a recruitment of the established genetic control of those organs into the patterning of chemoreceptive portion of the brain in the ancestral errant annelid. On the other hand, if the genes are not part of the same GRN and instead act independently in particular cell types (which is supported by non-corresponding, regionspecific expression of particular TFs in mushroom bodies and cerebral organs) a more complicated mechanism might account for the observed similarities. For instance, some of the cell types present in both organs might be homologues and derived from the common ancestor, but the organs containing those cell types are convergent and include other, unrelated and lineage-specific cell types. This could happen due to the reduction of the ciliated duct and the secretory cells and further integration of the neural part of the ancestral ciliated pits with the CNS in annelids. A solid phylogenetic position of Nemertea, analysis of function and interactions of the studied TFs as well as additional gene expression data from catenulids, macrostomids and Palaeoannelida are needed to ascertain on any of those evolutionary scenarios. 


\section{Conclusions}

In this study, we investigated the morphology and gene expression in the developing CNS of the nemertean Lineus ruber. At the moment of hatching, juveniles of $L$. ruber have already all major components of the adult nervous system, which indicates that further development is mostly related with increase in the size but not morphological complexity. This likeness corelates well with a similar predatory lifestyle of both juveniles and adults [40]. Comparison of gene expression in the brain of $L$. ruber and the annelid $P$. dumerilii $[41,42,49]$ indicates that complex brains, observed in those two animal species, evolved convergently by independent expansion of non-homologues regions of simpler ancestral brains. Such scenario corresponds with the similar conclusions drawn by comparative morphology $[21,64,88]$. In contrast to the discrepancies in gene expression in the brains, we observed that the same set of transcription factors, which is expressed in the mushroom bodies of $P$. dumerilii [49] is also expressed in the cerebral organs of $L$. ruber. These similarities might be a result of convergent recruitment of the same GRN into patterning of non-homologue organs or indicators of the homology of some cell types contributing to mushroom bodies and cerebral organs that could evolve from the cell type present in the lateral chemosensory ciliated pits of the hypothetical spiralian ancestor. Further studies on the cell-type level and functional interactions of the studied TFs are needed to fully resolve the level of homology, or convergence, between mushroom bodies and cerebral organs.

\section{Methods}

\section{Animal collection and morphological investigation}

Adult specimens of Lineus ruber were collected near Bergen, Norway (Fanafjord; GPS coordinates: $60.251845 \mathrm{~N}, 5.320947 \mathrm{E})$. The animals had dark red coloration with wide 
pigment-free areas in the terminal part of the head. Animals were kept in the laboratory in filtered seawater at $14^{\circ} \mathrm{C}$ with a daytime cycle: 13 hours of sunshine and 11 hours of darkness. Collection of egg masses and desired developmental stages, animal fixation as well as antibody, nuclear and EdU stainings followed the already established protocols [40].

Specimens for TEM investigation were fixed in 4\% PFA in PBS, rinsed in the same buffer, postfixed in $1 \%$ OsO4 diluted in PBS for 120 min at $4^{\circ} \mathrm{C}$, rinsed again and dehydrated in graded ethanol/acetone series. The samples were embedded in Epon 812 resin (Sigma Aldrich) and cut to semi- and ultrathin sections with a diamond knife (Diatome Histo Jumbo) using ultramicrotome Leica EM UC6. The ultrathin cross sections of cerebral organ were placed on formvar-covered (Fluka) single slot copper grids and stained with $1 \%$ uranyl acetate and lead citrate.

\section{Gene expression analysis}

Coding sequences for analyzed genes were identified in the transcriptome of $L$. ruber with the reciprocal TBLASTN search using orthologous protein sequences from $P$. dumerilii. Sequence of all of the newly identified genes were translated into protein sequences and aligned with reference sequences from other animals (Table S1). The alignments were trimmed either manually or with TrimAl software [120] and analyzed with FastTree v2.1 [121] in order to assess orthology of the analyzed genes (Figs. S1-5). All newly obtained sequences were submitted to GenBank (Accession numbers MW720144-MW720151).

Fragments of genes were amplified from cDNA library using specific primer pairs, cloned into pGEM-T Easy vectors (Promega, USA) and then transformed into competent Escherichia coli cells for amplification. Plasmid DNA was isolated and sequenced in both forward and reverse directions using T7 and SP6 primers to assure that the desirable genes were cloned. The 
antisense probes were transcribed from linearized DNA and labeled either with digoxigenin (for hybridization of single mRNA) or with dinitrophenol (for detection of second gene in double in situ hybridization). Whole mount in situ hybridization followed the same procedure as described for $L$. ruber juveniles in other studies $[39,40]$.

\section{Imaging and image processing}

Samples for confocal laser scanning microscopy (antibody staining and in situ hybridization) were mounted in Murray's clear and scanned in either Leica SP5 or Olympus FV3000 CLSM. Z-stacks of confocal scans were projected into 2D images in IMARIS 9.1.2. TEM microphotographs were obtained with Gatan ES500W camera mounted on transmission electron microscope Jeol JEM-1011. Both CLSM images and TEM micrographs were assembled in Adobe Illustrator CS6 into final figures. All the schematic drawings were done with Adobe Illustrator CS6.

\section{Acknowledgements}

We are grateful to all present and former members of the Comparative Developmental Biology Group, University of Bergen, who helped with the collection and culturing of Lineus viridis. We also would like to thank Naëlle Barabé, who cloned and prepared probe against dach gene. All TEM studies were carried out at the Shared Research Facility "Electron microscopy in life sciences" at Moscow State University.

\section{Authors' contributions}

LG conducted gene search and orthology assessments, cloned genes, performed in situ hybridization, arranged figures and drafted the manuscript. AB performed antibody staining, 
searched and cloned genes and performed in situ hybridization. IAC prepared, examined and photographed samples for TEM. AOA searched and cloned genes, performed antibody and EdU stainings. AH designed and coordinated the study and contributed to the writing. All authors read, accepted and approved the final version of the manuscript.

\section{Funding}

Research was supported by the European Research Council Community's Framework Program Horizon 2020 (2014-2020) ERC Grant Agreement 648861 and the Norwegian Research Council FRIPRO Grant 815194 to AH.

\section{References}

1. Giribet G, Edgecombe GD: Nemertea. In: The invertebrate tree of life. Princeton and Oxford: Princeton University Press; 2020: 412 - 423.

2. Kajihara H, Chernyshev AV, Sun S-C, Sundberg P, Crandall FB: Checklist of nemertean genera and species published between 1995 and 2007. Species Diversity 2008, 13(4):245-274.

3. Gibson R: Nemertean genera and species of the world: an annotated checklist of original names and description citations, synonyms, current taxonomic status, habitats and recorded zoogeographic distribution. J Nat Hist 1995, 29(2):271-561.

4. Dunn CW, Hejnol A, Matus DQ, Pang K, Browne WE, Smith SA, Seaver E, Rouse GW, Obst $M$, Edgecombe GD et al: Broad phylogenomic sampling improves resolution of the animal tree of life. Nature 2008, 452(7188):745-U745.

5. Laumer CE, Bekkouche N, Kerbl A, Goetz F, Neves RC, Sorensen MV, Kristensen RM, Hejnol A, Dunn CW, Giribet $G$ et al: Spiralian phylogeny informs the evolution of microscopic lineages. Curr Biol 2015, 25(15):2000-2006.

6. Laumer CE, Fernandez R, Lemer S, Combosch D, Kocot KM, Riesgo A, Andrade SCS, Sterrer W, Sørensen MV, Giribet G: Revisiting metazoan phylogeny with genomic sampling of all phyla. Proc Biol Sci 2019, 286(1906):20190831.

7. Marlétaz F, Peijnenburg K, Goto T, Satoh N, Rokhsar DS: A New Spiralian Phylogeny Places the Enigmatic Arrow Worms among Gnathiferans. Curr Biol 2019, 29(2):312318 e313.

8. Zverkov OA, Mikhailov KV, Isaev SV, Rusin LY, Popova OV, Logacheva MD, Penin AA, Moroz LL, Panchin YV, Lyubetsky VA et al: Dicyemida and Orthonectida: Two Stories of Body Plan Simplification. Front Genet 2019, 10:443.

9. Hejnol A, Obst M, Stamatakis A, Ott M, Rouse GW, Edgecombe GD, Martinez P, Baguñà $J$, Bailly $X$, Jondelius $U$ : Assessing the root of bilaterian animals with scalable 
phylogenomic methods. Proceedings of the Royal Society B: Biological Sciences 2009, 276(1677):4261-4270.

10. Kocot KM, Struck TH, Merkel J, Waits DS, Todt C, Brannock PM, Weese DA, Cannon JT, Moroz LL, Lieb B: Phylogenomics of Lophotrochozoa with consideration of systematic error. Systematic Biology 2017, 66(2):256-282.

11. Struck TH, Fisse F: Phylogenetic Position of Nemertea Derived from Phylogenomic Data. Molecular Biology and Evolution 2008, 25(4):728-736.

12. Giribet G, Dunn CW, Edgecombe GD, Hejnol A, Martindale MQ, Rouse GW: Assembling the Spiralian Tree of Life. In: Animal Evolution: Genomes, Fossils and Trees. Edited by Littlewood DTJ, Telford MJ. Oxford: Oxford University Press; 2009: 52-64.

13. Bleidorn C: Recent progress in reconstructing lophotrochozoan (spiralian) phylogeny. Org Divers Evol 2019:1-10.

14. von Döhren J: Nemertea. In: Evolutionary Developmental Biology of Invertebrates 2. Springer; 2015: 155-192.

15. Chernyshev AV: CLSM analysis of the phalloidin-stained muscle system of the nemertean proboscis and rhynchocoel. Zoological Science 2015, 32(6):547-560.

16. Turbeville J, Ruppert E: Comparative ultrastructure and the evolution of nemertines. American zoologist 1985, 25(1):53-71.

17. Mclntosh WC: A monograph of the British annelids: The Nemerteans. London: Ray Society; 1874.

18. Bürger O: Die Nemertinen des Golfes von Neapel und der angrenzenden MeeresAbschnitte, vol. 1: Engelmann; 1895.

19. Beckers P, Faller S, Loesel R: Lophotrochozoan neuroanatomy: An analysis of the brain and nervous system of Lineus viridis (Nemertea) using different staining techniques. Front Zool 2011, 8:17.

20. Beckers P: Nemertean nervous system: a comparative analysis. Universitäts-und Landesbibliothek Bonn; 2011.

21. Beckers $P$, Loesel $R$, Bartolomaeus $T$ : The nervous systems of basally branching nemertea (palaeonemertea). PLoS One 2013, 8(6):e66137.

22. Beckers P: The nervous systems of Pilidiophora (Nemertea). Zoomorphology 2015, 134(1):1-24.

23. Zaitseva OV, Petrov SA, Petrov AA: Sensory systems of Lineus ruber (Nemertea, Pilidiophora). Zoomorphology 2020, 139(4):447-459.

24. Punin MY, Zaitseva OV, Markosova TG: First data on monoamine- and peptidecontaining elements of the nervous system of nemertines. Dokl Biol Sci 2003, 393:565-567.

25. Zaitseva OV, Markosova TG: Choline acetyltransferase and NADPH-diaphorase activity in the nervous system and receptor organs of nemerteans. Dokl Biol Sci 2009, 428:427-429.

26. Zaitseva OV, Petrov SA: Biogenic amines in the nervous system of nemerteans. Dokl Biol Sci 2013, 451:228-230.

27. Gibson R: Nemerteans, vol. 178: Hutchinson; 1972.

28. Beckers $P$, Krämer D, Bartolomaeus $T$ : The nervous systems of Hoplonemertea (Nemertea). Zoomorphology 2018, 137(4):473-500.

29. Punnett RC: Lineus, vol. VII. London: Williams \& Norgate; 1901.

30. Ling EA: The structure and function of the cephalic organ of a nemertine Lineus ruber. Tissue Cell 1969, 1(3):503-524. 
31. Ling EA: Further investigations on the structure and function of cephalic organs of a nemertine Lineus ruber. Tissue and Cell 1970, 2(4):569-588.

32. Ferraris JD: Putative neuroendrocrine devices in the nemertina-an overview of structure and function. American zoologist 1985, 25(1):73-85.

33. Amerongen HM, Chia FS: Fine structure of the cerebral organs in hoplonemerteans (Nemertini), with a discussion of their function. Zoomorphology 1987, 107(3):145159.

34. Kepner WA, Taliaferro W: Sensory epithelium of pharynx and ciliated pits of Microstoma caudatum. The Biological Bulletin 1912, 23(1):42-59.

35. Loesel R, Heuer CM: The mushroom bodies-prominent brain centres of arthropods and annelids with enigmatic evolutionary origin. Acta zoologica 2010, 91(1):29-34.

36. Wolff GH, Strausfeld NJ: Genealogical correspondence of mushroom bodies across invertebrate phyla. Current Biology 2015, 25(1):38-44.

37. Nusbaum J, Oxner M: Die Embryonalentwicklung des Lineus ruber Müll. Ein Beitrag zur Entwicklungsgeschichte der Nemertinen. Z wiss Zool 1913, 107:78-197.

38. Schmidt G: Embryonic development of littoral nemertines Lineus desori (mihi, species nova) and Lineus ruber (OF Mülleri, 1774, GA Schmidt, 1945) in connection with ecological relation changes of mature individuals when forming the new species Lineus ruber. Zool Pol 1964, 14:75-122.

39. Martin-Duran JM, Pang K, Borve A, Le HS, Furu A, Cannon JT, Jondelius U, Hejnol A: Convergent evolution of bilaterian nerve cords. Nature 2018, 553(7686):45-50.

40. Martin-Duran JM, Vellutini BC, Hejnol A: Evolution and development of the adelphophagic, intracapsular Schmidt's larva of the nemertean Lineus ruber. Evodevo 2015, 6:28.

41. Denes AS, Jekely G, Steinmetz PR, Raible F, Snyman H, Prud'homme B, Ferrier DE, Balavoine $G$, Arendt $D$ : Molecular architecture of annelid nerve cord supports common origin of nervous system centralization in bilateria. Cell 2007, 129(2):277288.

42. Tessmar-Raible K, Raible F, Christodoulou F, Guy K, Rembold M, Hausen H, Arendt D: Conserved sensory-neurosecretory cell types in annelid and fish forebrain: insights into hypothalamus evolution. Cell 2007, 129(7):1389-1400.

43. Kerbl A, Martin-Duran JM, Worsaae K, Hejnol A: Molecular regionalization in the compact brain of the meiofaunal annelid Dinophilus gyrociliatus (Dinophilidae). EvoDevo 2016, 7(1):1-21.

44. Scimone ML, Kravarik KM, Lapan SW, Reddien PW: Neoblast specialization in regeneration of the planarian Schmidtea mediterranea. Stem cell reports 2014, 3(2):339-352.

45. Currie KW, Molinaro AM, Pearson BJ: Neuronal sources of hedgehog modulate neurogenesis in the adult planarian brain. Elife 2016, 5:e19735.

46. Santagata S, Resh C, Hejnol A, Martindale MQ, Passamaneck YJ: Development of the larval anterior neurogenic domains of Terebratalia transversa (Brachiopoda) provides insights into the diversification of larval apical organs and the spiralian nervous system. Evodevo 2012, 3(1):1-21.

47. Boyle MJ, Yamaguchi E, Seaver EC: Molecular conservation of metazoan gut formation: evidence from expression of endomesoderm genes in Capitella teleta (Annelida). EvoDevo 2014, 5(1):1-19. 
48. Klann $M$, Seaver EC: Functional role of pax6 during eye and nervous system development in the annelid Capitella teleta. Developmental biology 2019, 456(1):86103.

49. Tomer R, Denes AS, Tessmar-Raible K, Arendt D: Profiling by image registration reveals common origin of annelid mushroom bodies and vertebrate pallium. Cell 2010, 142(5):800-809.

50. Oda Y: Choline acetyltransferase: the structure, distribution and pathologic changes in the central nervous system. Pathology international 1999, 49(11):921-937.

51. Richter S, Loesel R, Purschke G, Schmidt-Rhaesa A, Scholtz G, Stach T, Vogt L, Wanninger $A$, Brenneis $G$, Döring $C$ : Invertebrate neurophylogeny: suggested terms and definitions for a neuroanatomical glossary. Frontiers in Zoology 2010, 7(1):29.

52. Charpignon V: Homeobox-containing genes in the nemertean Lineus: key players in the antero-posterior body patterning and in the specification of the visual structures. Reims; 2006.

53. Krämer D, Schmidt C, Podsiadlowski L, Beckers P, Horn L, von Döhren J: Unravelling the Lineus ruber/viridis species complex (Nemertea, Heteronemertea). Zoologica Scripta 2017, 46(1):111-126.

54. Cherneva IA, Chernyshev AV, Ekimova IA, Polyakova NE, Schepetov DM, Turanov SV, Neretina TV, Chaban EM, Malakhov VV: Species identity and genetic structure of nemerteans of the "Lineus ruber-viridis" complex (Muller, 1774) from Arctic waters (vol 42, pg 497, 2019). Polar Biology 2019, 42(3):507-508.

55. von Döhren J: Development of the Nervous System of Carinina ochracea (Palaeonemertea, Nemertea). Plos One 2016, 11(10).

56. Coe WR: The nervous system of pelagic nemerteans. The Biological Bulletin 1927, 53(2):123-138.

57. Sundberg $P$, Chernyshev AV, Kajihara H, Kanneby $T$, Strand M: Character-matrix based descriptions of two new nemertean (Nemertea) species. Zoological Journal of the Linnean Society 2009, 157(2):264-294.

58. Stricker SA: The morphology of Paranemertes sanjuanensis sp. n.(Nemertea, Monostilifera) from Washington, USA. Zoologica Scripta 1982, 11(2):107-115.

59. Helm C, Beckers P, Bartolomaeus T, Drukewitz SH, Kourtesis I, Weigert A, Purschke G, Worsaae $\mathrm{K}$, Struck TH, Bleidorn C: Convergent evolution of the ladder-like ventral nerve cord in Annelida. Frontiers in Zoology 2018, 15.

60. Orrhage L, Müller MCM: Morphology of the nervous system of Polychaeta (Annelida). Hydrobiologia 2005, 535:79-111.

61. Kerbl A, Bekkouche N, Sterrer W, Worsaae K: Detailed reconstruction of the nervous and muscular system of Lobatocerebridae with an evaluation of its annelid affinity. Bmc Evolutionary Biology 2015, 15.

62. Meyer NP, Carrillo-Baltodano A, Moore RE, Seaver EC: Nervous system development in lecithotrophic larval and juvenile stages of the annelid Capitella teleta. Frontiers in Zoology 2015, 12.

63. Carrillo-Baltodano AM, Boyle MJ, Rice ME, Meyer NP: Developmental architecture of the nervous system in Themiste lageniformis (Sipuncula): New evidence from confocal laser scanning microscopy and gene expression. Journal of Morphology 2019, 280(11):1628-1650. 
64. Beckers $P$, Helm C, Purschke $G$, Worsaae $K$, Hutchings $P$, Bartolomaeus $T$ : The central nervous system of Oweniidae (Annelida) and its implications for the structure of the ancestral annelid brain. Frontiers in zoology 2019, 16(1):1-21.

65. Todaro MA, Dal Zotto M, Leasi F: An Integrated Morphological and Molecular Approach to the Description and Systematisation of a Novel Genus and Species of Macrodasyida (Gastrotricha). Plos One 2015, 10(7).

66. Rothe $\mathrm{BH}$, Schmidt-Rhaesa A, Kieneke A: The nervous system of Neodasys chaetonotoideus (Gastrotricha: Neodasys) revealed by combining confocal laserscanning and transmission electron microscopy: evolutionary comparison of neuroanatomy within the Gastrotricha and basal Protostomia. Zoomorphology 2011, 130(1):51-84.

67. Bekkouche N, Worsaae K: Neuromuscular study of early branching Diuronotus aspetos (Paucitubulatina) yields insights into the evolution of organs systems in Gastrotricha. Zoological Letters 2016, 2.

68. Gąsiorowski L, Bekkouche N, Worsaae K: Morphology and evolution of the nervous system in Gnathostomulida (Gnathifera, Spiralia). Organisms Diversity \& Evolution 2017, 17(2):447-475.

69. Bekkouche N, Worsaae K: Nervous system and ciliary structures of Micrognathozoa (Gnathifera): evolutionary insight from an early branch in Spiralia. Roy Soc Open Sci 2016, 3(10):160289.

70. Gąsiorowski L, Furu A, Hejnol A: Morphology of the nervous system of monogonont rotifer Epiphanes senta with a focus on sexual dimorphism between feeding females and dwarf males. Frontiers in zoology 2019, 16(1):1-13.

71. Hochberg R: Topology of the nervous system of Notommata copeus (Rotifera: Monogononta) revealed with anti-FMRFamide,-SCPb, and-serotonin (5-HT) immunohistochemistry. Invertebrate Biology 2007, 126(3):247-256.

72. Orrhage L: On the microanatomy of the cephalic nervous system of Nereidae (Polychaeta), with a preliminary discussion of some earlier theories on the segmentation of the polychaete brain. Acta Zoologica 1993, 74(2):145-172.

73. Heuer $\mathrm{CM}$, Muller $\mathrm{CH}$, Todt $\mathrm{C}$, Loesel $\mathrm{R}$ : Comparative neuroanatomy suggests repeated reduction of neuroarchitectural complexity in Annelida. Front Zool 2010, 7:13.

74. Williams EA, Verasztó C, Jasek S, Conzelmann M, Shahidi R, Bauknecht $P$, Mirabeau O, Jékely G: Synaptic and peptidergic connectome of a neurosecretory center in the annelid brain. Elife 2017, 6:e26349.

75. Murakami Y, Ogasawara M, Sugahara F, Hirano S, Satoh N, Kuratani S: Identification and expression of the lamprey Pax6 gene: evolutionary origin of the segmented brain of vertebrates. Development 2001, 128(18):3521-3531.

76. Corbin JG, Rutlin M, Gaiano N, Fishell G: Combinatorial function of the homeodomain proteins Nkx2. 1 and Gsh2 in ventral telencephalic patterning. Development 2003, 130(20):4895-4906.

77. Passamaneck YJ, Furchheim N, Hejnol A, Martindale MQ, Lüter C: Ciliary photoreceptors in the cerebral eyes of a protostome larva. EvoDevo 2011, 2(1):1-18.

78. Martin-Duran JM, Passamaneck YJ, Martindale MQ, Hejnol A: The developmental basis for the recurrent evolution of deuterostomy and protostomy. Nature ecology \& evolution 2016, 1(1):1-10. 
79. Vellutini BC, Hejnol A: Expression of segment polarity genes in brachiopods supports a non-segmental ancestral role of engrailed for bilaterians. Scientific reports 2016, 6(1):1-15.

80. Pineda D, Rossi L, Batistoni R, Salvetti A, Marsal M, Gremigni V, Falleni A, GonzalezLinares J, Deri $P$, Saló $E$ : The genetic network of prototypic planarian eye regeneration is Pax6 independent. Development 2002, 129(6):1423-1434.

81. Loosli F, Kmita-Cunisse M, Gehring WJ: Isolation of a Pax-6 homolog from the ribbonworm Lineus sanguineus. Proceedings of the National Academy of Sciences 1996, 93(7):2658-2663.

82. Gehring WJ, Ikeo K: Pax 6: mastering eye morphogenesis and eye evolution. Trends in genetics 1999, 15(9):371-377.

83. Quiring R, Walldorf $U$, Kloter $U$, Gehring WJ: Homology of the eyeless gene of Drosophila to the Small eye gene in mice and Aniridia in humans. Science 1994, 265(5173):785-789.

84. Kozmik Z: Pax genes in eye development and evolution. Current opinion in genetics \& development 2005, 15(4):430-438.

85. Gąsiorowski L, Hejnol A: Hox gene expression during development of the phoronid Phoronopsis harmeri. EvoDevo 2020, 11(1):2.

86. Andrikou C, Passamaneck YJ, Lowe CJ, Martindale MQ, Hejnol A: Molecular patterning during the development of Phoronopsis harmeri reveals similarities to rhynchonelliform brachiopods. EvoDevo 2019, 10(1):1-15.

87. Forsthoefel DJ, James NP, Escobar DJ, Stary JM, Vieira AP, Waters FA, Newmark PA: An RNAi screen reveals intestinal regulators of branching morphogenesis, differentiation, and stem cell proliferation in planarians. Developmental cell 2012, 23(4):691-704.

88. Beckers $\mathrm{P}$, Helm C, Bartolomaeus $\mathrm{T}$ : The anatomy and development of the nervous system in Magelonidae (Annelida)-insights into the evolution of the annelid brain . BMC evolutionary biology 2019, 19(1):1-21.

89. Hejnol A, Lowe CJ: Embracing the comparative approach: how robust phylogenies and broader developmental sampling impacts the understanding of nervous system evolution. Philos T R Soc B 2015, 370(1684).

90. Magarlamov TY, Chernyshev AV: Ultrastructural study of the proboscis of Malacobdella grossa (Nemertea: Hoplonemertea). Journal of Natural History 2010, 44(37-40):2349-2361.

91. Luo YJ, Kanda M, Koyanagi R, Hisata K, Akiyama T, Sakamoto H, Sakamoto T, Satoh N: Nemertean and phoronid genomes reveal lophotrochozoan evolution and the origin of bilaterian heads. Nat Ecol Evol 2018, 2(1):141-151.

92. Maslakova SA: Development to metamorphosis of the nemertean pilidium larva. Frontiers in Zoology 2010, 7(1):30.

93. Kumamoto T, Hanashima C: Evolutionary conservation and conversion of Foxg1 function in brain development. Development, growth \& differentiation 2017, 59(4):258-269.

94. Miura H, Yanazawa M, Kato K, Kitamura K: Expression of a novel aristaless related homeobox gene 'Arx' in the vertebrate telencephalon, diencephalon and floor plate. Mechanisms of development 1997, 65(1-2):99-109.

95. Gécz J, Cloosterman D, Partington M: ARX: a gene for all seasons. Current opinion in genetics \& development 2006, 16(3):308-316. 
96. Melkman T, Sengupta P: Regulation of chemosensory and GABAergic motor neuron development by the C. elegans Aristaless/Arx homolog alr-1. Development 2005, 132(8):1935-1949.

97. Melkman TJ: Studying neuronal development in Caenorhabditis elegans: The role of the ARX homolog, alr-1. Brandeis University; 2005.

98. Schiemann SM, Martin-Duran JM, Børve A, Vellutini BC, Passamaneck YJ, Hejnol A: Clustered brachiopod Hox genes are not expressed collinearly and are associated with lophotrochozoan novelties. Proc Natl Acad SciU S A 2017, 114(10):E1913-E1922.

99. Gąsiorowski L, Hejnol A: Hox gene expression in postmetamorphic juveniles of the brachiopod Terebratalia transversa. EvoDevo 2019, 10:1.

100. Fischer A: Mesoderm Formation and Muscle Development of Platynereis dumerilli (Nereididae, Annelida). Freie Universität Berlin; 2010.

101. Hilgers L, Hartmann S, Hofreiter M, von Rintelen T: Novel genes, ancient genes, and gene co-option contributed to the genetic basis of the radula, a molluscan innovation. Molecular biology and evolution 2018, 35(7):1638-1652.

102. Holmgren NF: Zur vergleichenden anatomie des gehirns: von polychaeten. onychophoren, xiphosuren, arachniden, crustaceen, myriapoden und insekten. Vorstudien zu einer phylogenie der anthropoden, vol. 56: Kungl Svenska Vetenskaps Handl 1916.

103. Hanström B: Untersuchungen über die relative Größe der Gehirnzentren verschiedener Arthropoden unter Berücksichtigung der Lebensweise. Z Mikr Anat Forsch 1926, 7:139-190.

104. Hanström B: Vergleichende Anatomie des Nervensystems der wirbellosen Tiere. Berlin, Heidelberg, New York: Julias Springer; 1928.

105. Strausfeld NJ, Hansen L, Li Y, Gomez RS, Ito K: Evolution, discovery, and interpretations of arthropod mushroom bodies. Learning \& memory 1998, 5(1):1137.

106. Heuer C, Loesel R: Three-dimensional reconstruction of mushroom body neuropils in the polychaete species Nereis diversicolor and Harmothoe areolata (Phyllodocida, Annelida). Zoomorphology 2009, 128(3):219-226.

107. Heuer C, Loesel R: Immunofluorescence analysis of the internal brain anatomy of Nereis diversicolor (Polychaeta, Annelida). Cell and Tissue Research 2008, 331(3):713724.

108. Purschke G, Bleidorn C, Struck T: Systematics, evolution and phylogeny of Annelidaa morphological perspective. Mem Museum Victoria 2014, 71:247-269.

109. Rimskaya-Korsakova NN, Kristof A, Malakhov VV, Wanninger A: Neural architecture of Galathowenia oculata Zach, 1923 (Oweniidae, Annelida). Frontiers in zoology 2016, 13(1):1-19.

110. Schmidbaur H, Schwaha T, Franzkoch R, Purschke G, Steiner G: Within-family plasticity of nervous system architecture in Syllidae (Annelida, Errantia). Frontiers in zoology 2020, 17(1):1-44.

111. Flögel J: Über den feineren Bau des Arthropodengehirns. Tageblatt der Versammlung Deutscher Naturforscher und Ärzte 1876, 49:115-120.

112. Kenyon F: The meaning and structure of the so-called "mushroom bodies" of the hexapod brain. The American Naturalist 1896, 30(356):643-650.

113. Strausfeld NJ, Mok Strausfeld C, Loesel R, Rowell D, Stowe S: Arthropod phylogeny: onychophoran brain organization suggests an archaic relationship with a chelicerate 
stem lineage. Proceedings of the Royal Society B: Biological Sciences 2006, 273(1596):1857-1866.

114. Strausfeld NJ, Mok Strausfeld C, Stowe S, Rowell D, Loesel R: The organization and evolutionary implications of neuropils and their neurons in the brain of the onychophoran Euperipatoides rowelli. Arthropod structure \& development 2006, 35(3):169-196.

115. Church SH, Extavour CG: Null hypotheses for developmental evolution. Development 2020, 147(8).

116. Kepner WA, Cash J: Ciliated pits of Stenostoma. Journal of Morphology 1915, 26(2):235-245.

117. Ott HN: A study of Stenostoma leucops O. Schm. Journal of Morphology 1892, 7(3):263-304.

118. Laumer CE, Hejnol A, Giribet G: Nuclear genomic signals of the 'microturbellarian'roots of platyhelminth evolutionary innovation. elife 2015, 4:e05503.

119. Nielsen C: Animal evolution. Interrelationships of the living phyla. Oxford (UK): Oxford University Press; 1995.

120. Capella-Gutierrez S, Silla-Martinez JM, Gabaldon T: trimAl: a tool for automated alignment trimming in large-scale phylogenetic analyses. Bioinformatics 2009, 25(15):1972-1973.

121. Price MN, Dehal PS, Arkin AP: FastTree 2-Approximately Maximum-Likelihood Trees for Large Alignments. Plos One 2010, 5(3). 


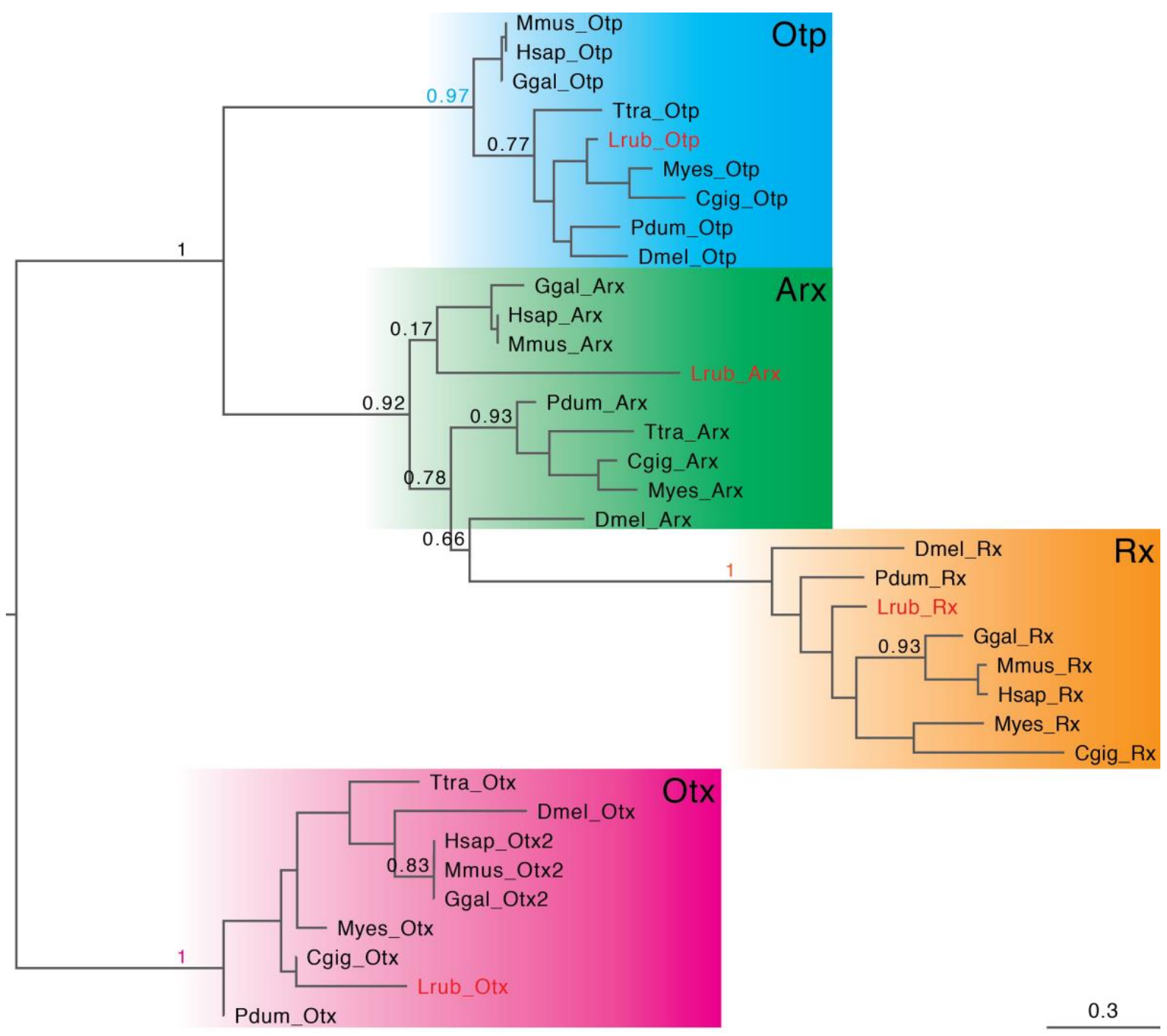

Fig. S1. Phylogenetic analysis of PRD-class homeobox transcription factors. SH-like support values are shown for the important nodes. Scale bar on the lower right corner shows amino acid substitution rate per site. Sequences from $L$. ruber are marked in red. For abbreviation and source of other sequences see table S1. 


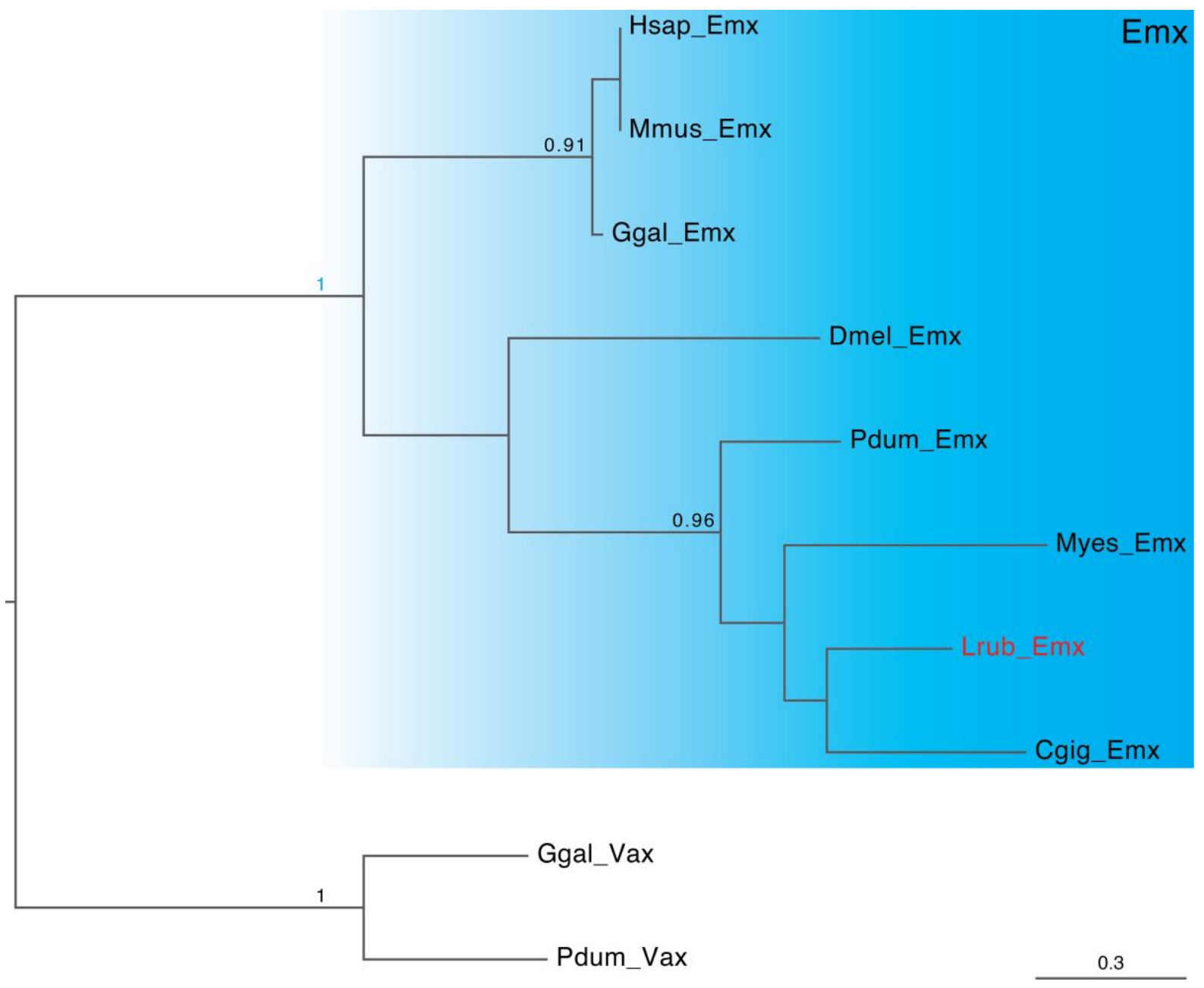

Fig. S2. Phylogenetic analysis of Emx sequences. SH-like support values are shown for the important nodes. Scale bar on the lower right corner shows amino acid substitution rate per site. Sequence from $L$. ruber is marked in red. For abbreviation and source of other sequences see table S1. 


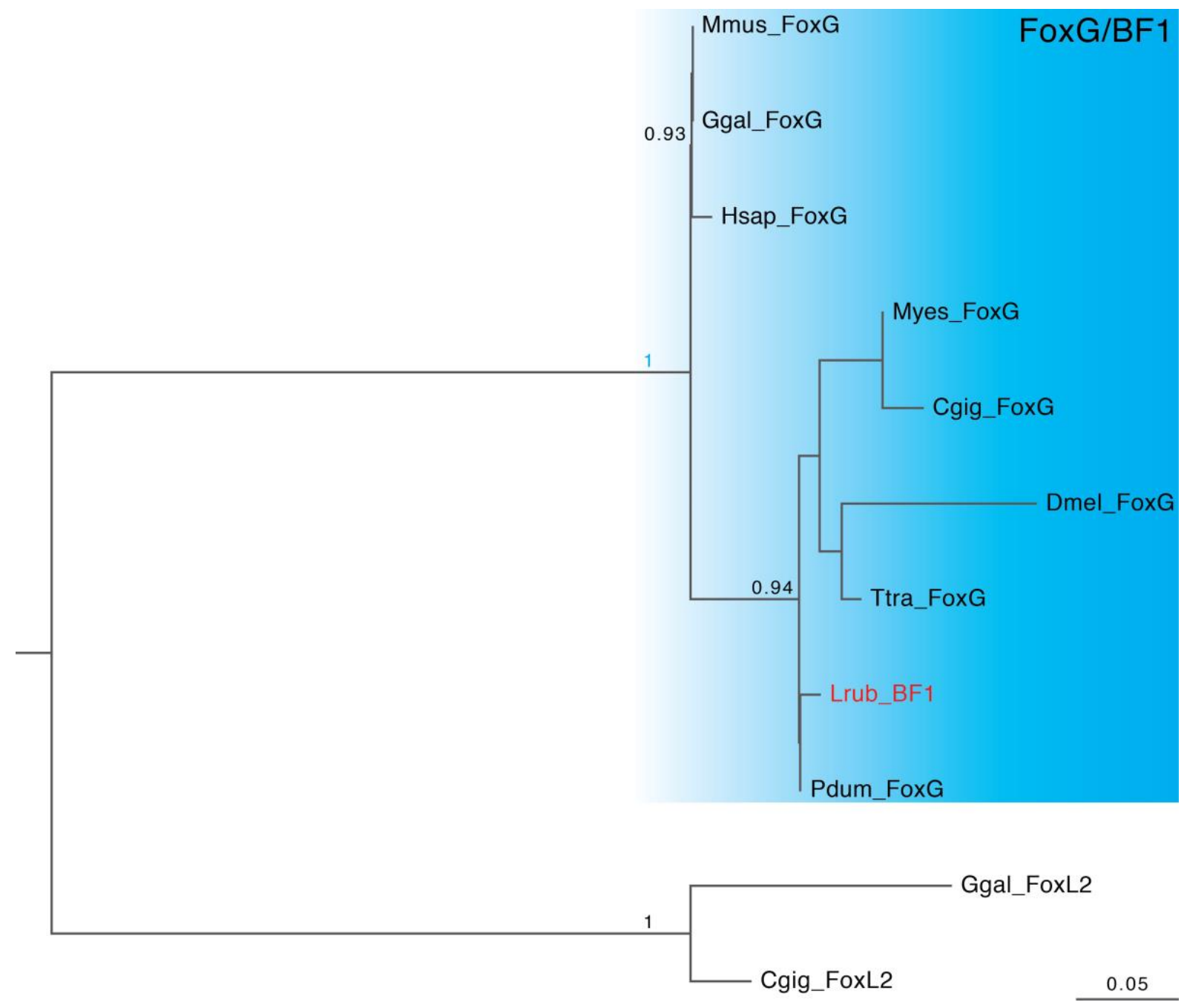

Fig. S3. Phylogenetic analysis of Fox sequences. SH-like support values are shown for the important nodes. Scale bar on the lower right corner shows amino acid substitution rate per site. Sequence from $L$. ruber is marked in red. For abbreviation and source of other sequences see table S1. 


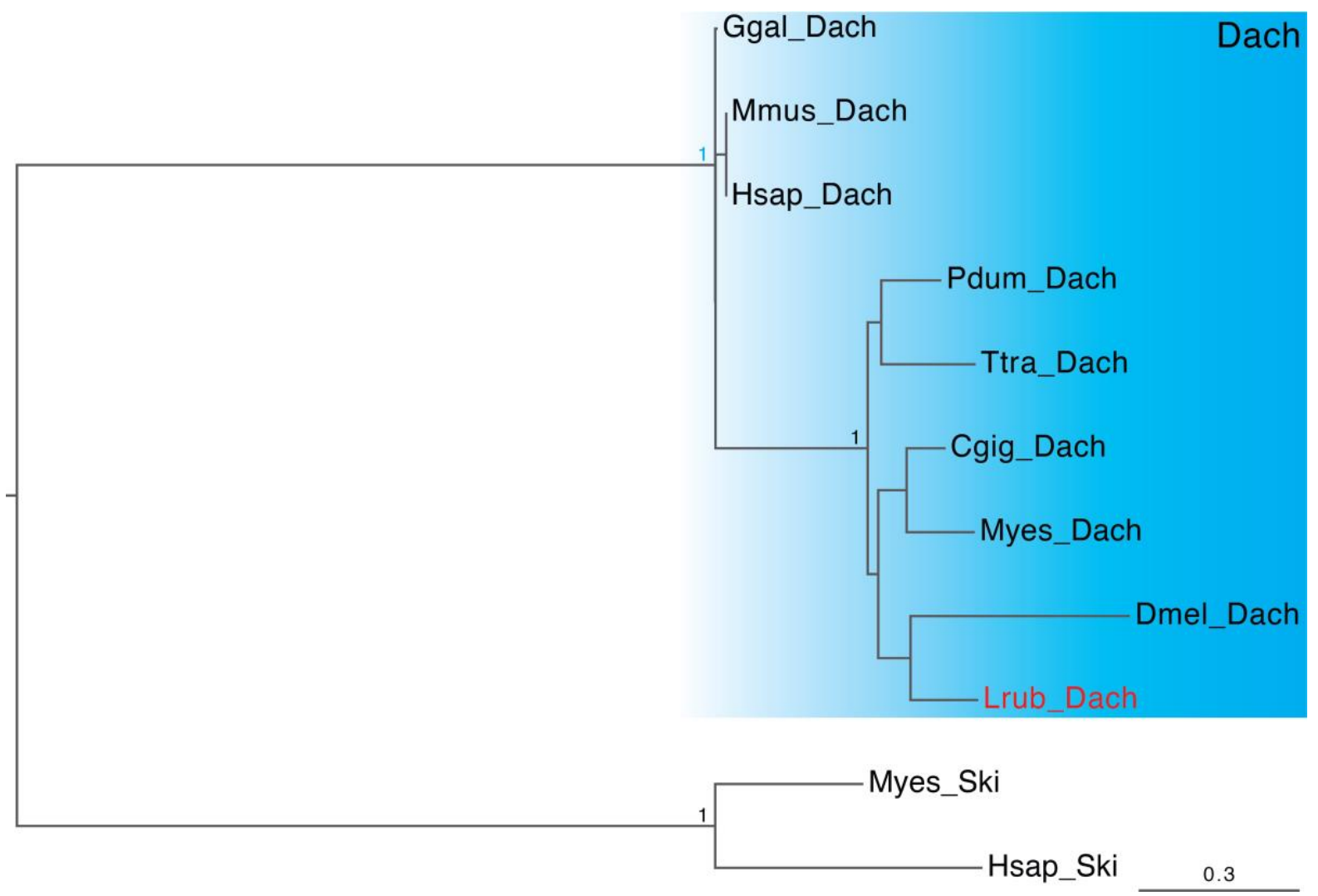

Fig. S4. Phylogenetic analysis of Dach sequences. SH-like support values are shown for the important nodes. Scale bar on the lower right corner shows amino acid substitution rate per site. Sequence from $L$. ruber is marked in red. For abbreviation and source of other sequences see table S1. 


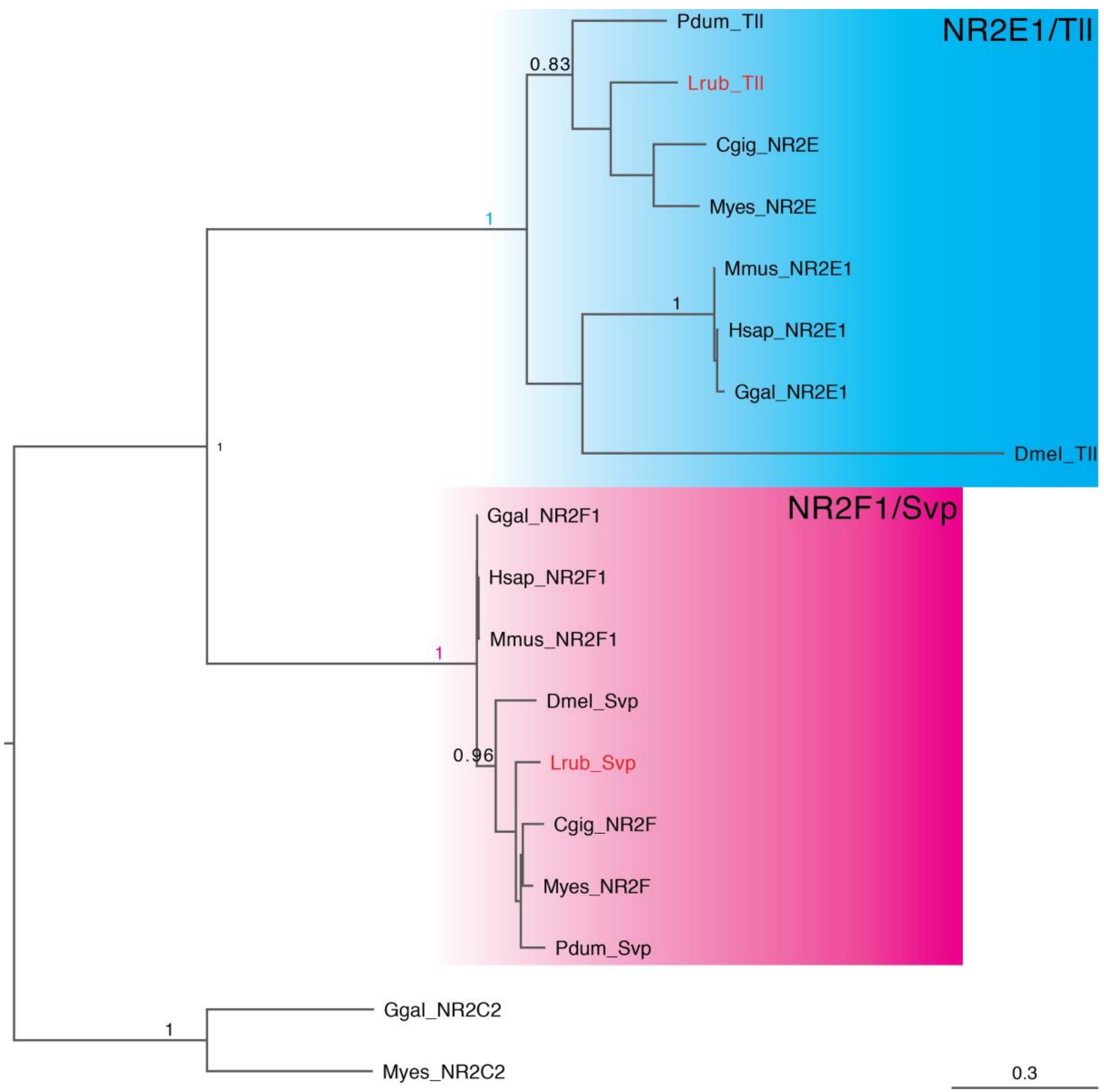

Fig. S5. Phylogenetic analysis of nuclear receptor subfamily 2. SH-like support values are shown for the important nodes. Scale bar on the lower right corner shows amino acid substitution rate per site. Sequences from $L$. ruber are marked in red. For abbreviation and source of other sequences see table S1. 
Table S1. Sequences used in phylogenetic analyses

\begin{tabular}{|c|c|c|c|c|}
\hline label & gene & clade & species & accession no \\
\hline Pdum_Rx & $\mathrm{Rx}$ & Annelida & Platynereis dumerilii & AAU20320.1 \\
\hline Myes_Rx & $\mathrm{Rx}$ & Mollusca & Mizuhopecten yessoensis & XP_021372253.1 \\
\hline Cgig_Rx & $\mathrm{Rx}$ & Mollusca & Crassostrea gigas & XP_011427710.2 \\
\hline Dmel_Rx & $\mathrm{Rx}$ & Arthropoda & Drosophila melanogaster & NP_726006.3 \\
\hline Ggal_Rx & $\mathrm{Rx}$ & Chordata & Gallus gallus & NP_989435.2 \\
\hline Mmus_Rx & $\mathrm{Rx}$ & Chordata & Mus musculus & NP_038861.2 \\
\hline Hsap_Rx & $\mathrm{Rx}$ & Chordata & Homo sapiens & NP_038463.2 \\
\hline Pdum_Arx & Arx & Annelida & Platynereis dumerilii & ADG26723.1 \\
\hline Ttra_Arx & Arx & Brachiopoda & Terebratalia transversa & AQU64617.1 \\
\hline Cgig_Arx & Arx & Mollusca & Crassostrea gigas & XP_011423594.2 \\
\hline Myes_Arx & Arx & Mollusca & Mizuhopecten yessoensis & XP_021346595.1 \\
\hline Dmel_Arx & Arx & Arthropoda & Drosophila melanogaster & NP_722629.1 \\
\hline Mmus_Arx & Arx & Chordata & Mus musculus & EDL29739.1 \\
\hline Ggal_Arx & Arx & Chordata & Gallus gallus & XP_025002251.1 \\
\hline Hsap_Arx & Arx & Chordata & Homo sapiens & NP_620689.1 \\
\hline Lrub_Otx & Otx & Nemertea & Lineus ruber & AMR72028.1 \\
\hline Pdum_Otx & Otx & Annelida & Platynereis dumerilii & CAC19028.1 \\
\hline Ttra_Otx & Otx & Brachiopoda & Terebratalia transversa & ADZ24785.1 \\
\hline Cgig_Otx & Otx & Mollusca & Crassostrea gigas & XP_011415946.1 \\
\hline Myes_Otx & Otx & Mollusca & Mizuhopecten yessoensis & XP_021353640.1 \\
\hline Dmel_Otx & Otx & Arthropoda & Drosophila melanogaster & NP_511091.4 \\
\hline Hsap_Otx2 & Otx2 & Chordata & Homo sapiens & NP_001257454.1 \\
\hline Mmus_Otx2 & Otx2 & Chordata & Mus musculus & NP_001273410.1 \\
\hline Ggal_Otx2 & Otx2 & Chordata & Gallus gallus & NP_989851.2 \\
\hline Myes_Otp & Otp & Mollusca & Mizuhopecten yessoensis & XP_021340833.1 \\
\hline Cgig_Otp & Otp & Mollusca & Crassostrea gigas & XP_011436433.1 \\
\hline Ttra_Otp & Otp & Brachiopoda & Terebratalia transversa & AEZ03829.1 \\
\hline Pdum_Otp & Otp & Annelida & Platynereis dumerilii & ABR68849.1 \\
\hline Dmel_Otp & Otp & Arthropoda & Drosophila melanogaster & NP_001097388.2 \\
\hline Mmus_Otp & Otp & Chordata & Mus musculus & XP_006517630.1 \\
\hline Ggal_Otp & Otp & Chordata & Gallus gallus & XP_003643004.1 \\
\hline Hsap_Otp & Otp & Chordata & Homo sapiens & NP_115485.1 \\
\hline Pdum_Emx & Emx & Annelida & Platynereis dumerilii & ADG26729.1 \\
\hline Myes_Emx & Emx & Mollusca & Mizuhopecten yessoensis & XP_021359646.1 \\
\hline Cgig_Emx & Emx & Mollusca & Crassostrea gigas & XP_011414574.2 \\
\hline Dmel_Emx & Emx & Arthropoda & Drosophila melanogaster & CAA35965.1 \\
\hline Ggal_Emx & Emx & Chordata & Gallus gallus & XP_001232151.3 \\
\hline Hsap_Emx & Emx & Chordata & Homo sapiens & NP_004088.2 \\
\hline Mmus_Emx & Emx & Chordata & Mus musculus & NP_034261.1 \\
\hline
\end{tabular}


Table S1. Continued.

\begin{tabular}{|c|c|c|c|c|}
\hline label & gene & clade & species & accession no \\
\hline Ggal_Vax & Vax & Chordata & Gallus gallus & AAF20017.1 \\
\hline Pdum_Vax & Vax & Annelida & Platynereis dumerilii & ABR68848.1 \\
\hline Pdum_FoxG & FoxG & Annelida & Platynereis dumerilii & ADG26725.1 \\
\hline Myes_FoxG & FoxG & Mollusca & Mizuhopecten yessoensis & XP_021363790.1 \\
\hline Cgig_FoxG & FoxG & Mollusca & Crassostrea gigas & XP_011427689.2 \\
\hline Ttra_FoxG & FoxG & Brachiopoda & Terebratalia transversa & AEZ03828.1 \\
\hline Dmel_FoxG & FoxG & Arthropoda & Drosophila melanogaster & NP_476834.1 \\
\hline Ggal_Foxg & FoxG & Chordata & Gallus gallus & NP_990524.1 \\
\hline Mmus_FoxG & FoxG & Chordata & Mus musculus & NP_001153584.1 \\
\hline Hsap_FoxG & FoxG & Chordata & Homo sapiens & AAH50072.1 \\
\hline Ggal_FoxL2 & FoxL2 & Chordata & Gallus gallus & AEE80502.1 \\
\hline Cgig_FoxL2 & FoxL2 & Mollusca & Crassostrea gigas & NP_001295827.1 \\
\hline Pdum_Dach & Dach & Annelida & Platynereis dumerilii & ADG26728.1 \\
\hline Cgig_Dach & Dach & Mollusca & Crassostrea gigas & XP_011445430.2 \\
\hline Myes_Dach & Dach & Mollusca & Mizuhopecten yessoensis & XP_021340456.1 \\
\hline Ttra_Dach & Dach & Brachiopoda & Terebratalia transversa & AJV21306.1 \\
\hline Dmel_Dach & Dach & Arthropoda & Drosophila melanogaster & NP_723968.1 \\
\hline Hsap_Dach & Dach & Chordata & Homo sapiens & EAW80509.1 \\
\hline Mmus_Dach & Dach & Chordata & Mus musculus & XP_036014326.1 \\
\hline Ggal_Dach & Dach & Chordata & Gallus gallus & AAL76234.1 \\
\hline Myes_Ski & Ski & Mollusca & Mizuhopecten yessoensis & XP_021339316.1 \\
\hline Hsap_Ski & Ski & Chordata & Homo sapiens & NP_003027.1 \\
\hline Pdum_Svp & $\mathrm{NR} 2 \mathrm{~F}$ & Annelida & Platynereis dumerilii & ADG26733.1 \\
\hline Pdum_Tll & NR2E & Annelida & Platynereis dumerilii & ADG26734.1 \\
\hline Myes_NR2F & $\mathrm{NR} 2 \mathrm{~F}$ & Mollusca & Mizuhopecten yessoensis & XP_021372361.1 \\
\hline Cgig_NR2F & $\mathrm{NR} 2 \mathrm{~F}$ & Mollusca & Crassostrea gigas & XP_019917917.1 \\
\hline Dmel_Svp & $\mathrm{NR} 2 \mathrm{~F}$ & Arthropoda & Drosophila melanogaster & NP_001369011.1 \\
\hline Mmus_NR2F1 & NR2F1 & Chordata & Mus musculus & EDL37125.1 \\
\hline Ggal_NR2F1 & NR2F1 & Chordata & Gallus gallus & XP_003643114.1 \\
\hline Hsap_NR2F1 & NR2F1 & Chordata & Homo sapiens & NP_005645.1 \\
\hline Cgig_NR2E & NR2E & Mollusca & Crassostrea gigas & XP_011438581.1 \\
\hline Myes_NR2E & NR2E & Mollusca & Mizuhopecten yessoensis & XP_021369330.1 \\
\hline Dmel_TII & NR2E & Arthropoda & Drosophila melanogaster & NP_524596.1 \\
\hline Ggal_NR2E1 & NR2E1 & Chordata & Gallus gallus & NP_990501.1 \\
\hline Hsap_NR2E1 & NR2E1 & Chordata & Homo sapiens & NP_003260.1 \\
\hline Mmus_NR2E1 & NR2E1 & Chordata & Mus musculus & NP_689415.1 \\
\hline Ggal_NR2C2 & NR2C2 & Chordata & Gallus gallus & $X P_{-} 414462.3$ \\
\hline Myes_NR2C2 & $\mathrm{NR} 2 \mathrm{C} 2$ & Mollusca & Mizuhopecten yessoensis & $X P \_414462.3$ \\
\hline
\end{tabular}

